\title{
An Action Research Study on Using Cooperative Learning During Graphic Design Classroom Crits
}

Anise V. Simpson

Cedarville University

Follow this and additional works at: http://digitalcommons.cedarville.edu/education_theses

Part of the Art Education Commons, and the Higher Education and Teaching Commons

\section{Recommended Citation}

Simpson, Anise V., "An Action Research Study on Using Cooperative Learning During Graphic Design Classroom Crits" (2011). Master of Education Research Theses. 47.

http://digitalcommons.cedarville.edu/education_theses/47 
AN ACTION RESEARCH STUDY ON USING COOPERATIVE LEARNING

DURING GRAPHIC DESIGN CLASSROOM CRITS

\author{
A thesis submitted in partial fulfillment \\ for the requirements of the degree \\ Masters of Education
}

\begin{abstract}
By
ANISE VERLENE SIMPSON

B.S. in Design, University of Cincinnati, 1994
\end{abstract}

2011

Cedarville University 


\section{CEDARVILLE UNIVERSITY \\ SCHOOL OF GRADUATE STUDIES}

July 6, 2011

I HEREBY RECOMMEND THAT THE THESIS PREPARED UNDER MY SUPERVISION BY Anise Verlene Simpson ENTITLED An Action Research Study on Using Cooperative Learning During Graphic Design Classroom Crits BE ACCEPTED IN PARTIAL FULFILLMENT OF THE REQUIREMENTS FOR THE DEGREE OF Master of Education.

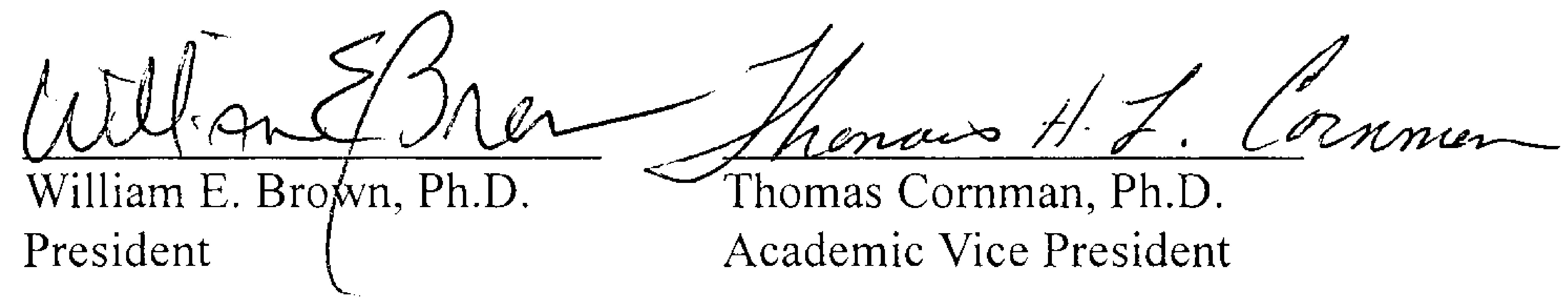

\section{Maks Mochain} Mark D. McClain, Ph.D. Associate Academic Vice President College of Professions

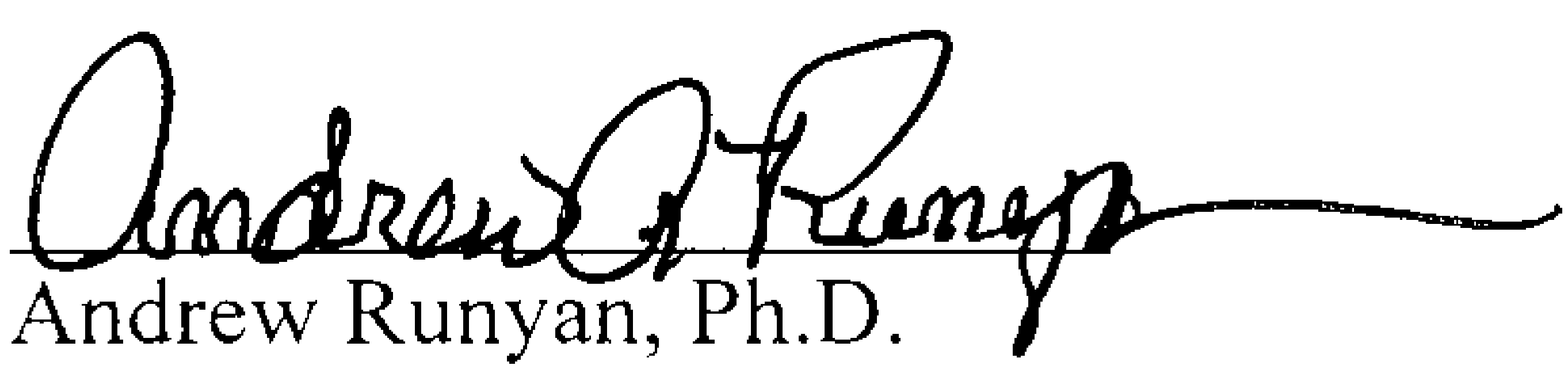

Thesis / Project Advisor Graduate School Dean

\section{Stephen S. Gruber, Ed.D.}

Education Department Chair

Director M.Ed. Program

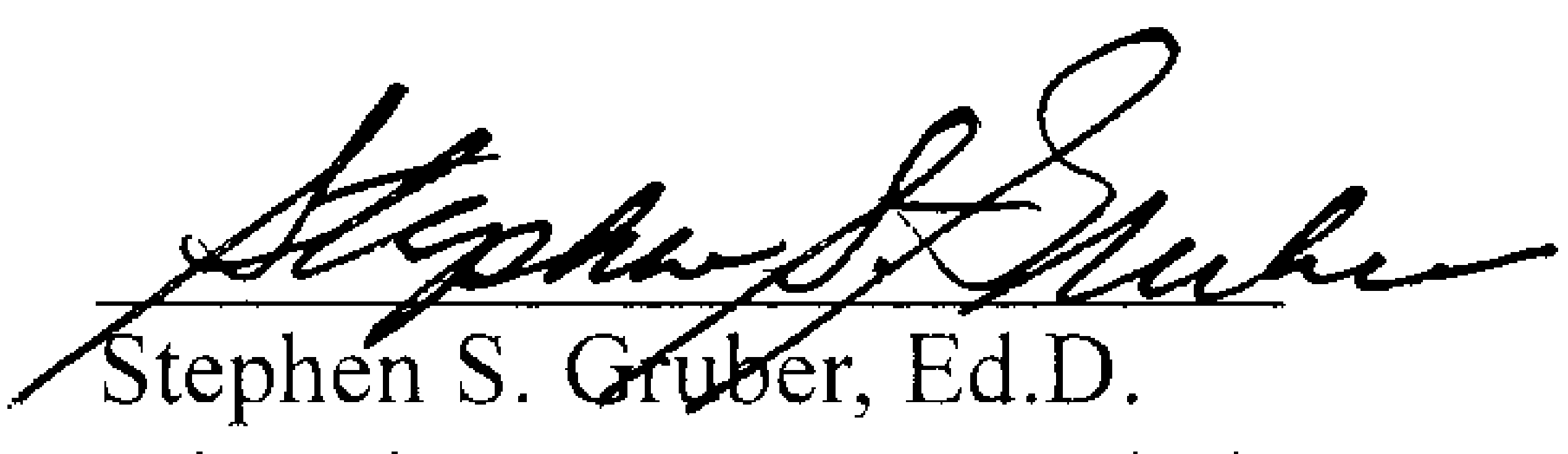




\begin{abstract}
Simpson, Anise Verlene. M.Ed. Education Department, Cedarville University, 2011. An Action Research Study on Using Cooperative Learning During Graphic Design Classroom Crits.
\end{abstract}

The author of this action research study surveyed both graphic design students and graphic design instructors about their critique experiences to discover instructors and students both identified a lack of student participation as well as the issue of students getting hurt feelings and becoming discouraged as common critique concerns. The author designed and implemented a treatment called Design Structures to increase student participation during crits. To improve the quality of experience of design students during crits, the author incorporated cooperative learning strategies developed by Spencer and Miguel Kagan (2009) into the Design Structures treatment. The author used the experience sampling method (Csikzentmihalyi, Rathunde, \& Whalen, 1993) to compare the quality of experience of community college design students during whole-class crits and during Design Structures crits. Quality of experience levels were consistently higher overall for students during cooperative learning -specifically in the areas of self-esteem, perceived importance of task, challenge, and skill. Furthermore, more design students were in flow and less apathetic during decentralized crits using Design Structures than centralized crits utilizing teacher-led whole-class instruction. In fact, results showed no design students as apathetic during Design Structures crits. The author interviewed design instructors to discover their perceptions, as well as misconceptions, of cooperative learning methodology in addition to their openness to learning more about how to effectively incorporate cooperative learning into their critique pedagogy. 


\section{Table of Contents}

List of Figures $\quad$ vi

List of Tables $\quad$ vii

Acknowledgements $\quad$ viii

CHAPTER I: Introduction 1

Educational Significance $\quad 1$

Statement of the Issue 3

Significance of the Study 4

Biblical Integration $\quad 5$

CHAPTER II: Review of the Literature 9

The Critique Experience $\quad 9$

$\begin{array}{ll}\text { Cooperative Learning } & 19\end{array}$

Action Research and the Experience Sampling Method 25

CHAPTER III: Methodology and Procedures 27

Scope of the Study and Delimitations $\quad 27$

$\begin{array}{ll}\text { Participants } & 27\end{array}$

$\begin{array}{lr}\text { Course Information } & 28\end{array}$

$\begin{array}{lr}\text { The Classroom Setting } & 28\end{array}$

Procedures and Data Collection $\quad 29$

The Treatment: Design Structures 31

CHAPTER IV: Results $\quad 36$

Bad Critique Perceptions 36

Good Critique Perceptions 38 
Difficult Aspects of Critiques

Quality of Experience Comparisons

Faculty Practices and Attitudes

CHAPTER V: Summary

60

Conclusions

Discussion

Recommendations

Appendix A - Course Master Syllabus

Appendix B - Design Critique Survey

Appendix C - Experience Sampling Method (ESM) Questionnaire

Appendix D - Round Robin All Write Consensus Questions - 1st Interruption

Appendix E-Project 5 Lesson Objectives - Ist Interruption

Appendix F - Round Robin All Write Consensus Questions -2nd Interruption

76

Appendix G - Project 8 Lesson Objectives -2nd Intermption

Appendix H - Design Faculty Interview Questions 


\section{List of Figures}

1 Details of Participant Population and Data Collection Sequence 


\section{List of Tables}

1 Frequencies of Students' and Instructors' Perceptions of Bad Critiques

2 Frequencies of Students' and Instructors' Perceptions of Good Critiques

3 Frequencies of Students' Thoughts Across Instructional Context

4 Descriptive Statistics for Quality of Experience Variables

$5 \quad$ Frequency of Flow Groups Across Instructional Context 


\section{Acknowledgements}

I would like to acknowledge those who have helped to make this project come together. First, I would like to thank God for leading me to pursue a graduate education at Cedarville University and for allowing me to successfully complete that education so that I may be better equipped to do the work He has prepared for me. Also, I am thankful for the Cedarville University Education faculty for their collective wisdom and educational guidance. Dr. Eddie Baumann, Dr. Andy Runyan, and Dr. Chi-en Hwang were particularly helpful in assisting me throughout the writing process of this study. I also would like to thank Dr. Phil Bassett for validating and encouraging the use of cooperative learning structures with adult instruction by implementing its use during his own graduate level pedagogy.

Second, I would like to thank the amazing faculty and students of the Visual Communications Department of Sinclair Community College for their time and input during this action research study. Their participation demonstrated their sincere interest and dedication to maximizing the effectiveness of instructional experiences within their own learning community. I particularly wish to thank Paul Schilling for his time, cooperation, and encouragement during the data collection phase of this project.

Third, I would like to thank Dean Robert Probst and Professor Gordon Salchow, AIGA Fellow from the School of Design of the University of Cincinnati's College of Design, Architecture, Art, and Planning. The wisdom these world-renowned Graphic Design educators shared during their respective interviews as experts within the field of Graphic Design was invaluable. I only wish I could have included more from their interviews in this project.

Fourth, I would like to thank my family and friends for continuing to support and encourage me throughout my graduate studies at Cedarville University. This accomplishment is theirs as much as it is mine. Julia Kranenburg was extremely helpful with data analysis. I particularly wish to thank my son Nathan for his patience and cooperation and for completing his own eighth grade studies with second honors. We are truly blessed! 


\section{Chapter I: Introduction}

\section{Educational Significance}

Visual arts and design students must develop visual proficiency. They must be able to effectively communicate and express themselves using visual language. Research suggests an effective model of visual education consists of the four essential elements of (1) studio-based experience, (2) working with materials, (3) relationships of trust, and (4) applied aesthetic understanding (Dinham, Grushka, MacCallum, Pascoe, Wright, \& Brown, 2007). Visual education has its foundation in the concept of "learning by doing." The studio-based learning environment allows students to build relationships with teachers, peers and themselves in order to develop confidence in the process of learning by doing. Hands-on experiences in the studio-based classroom teach students how to integrate the steps of the creative design process into how they work. Students demonstrate what they are learning as they create prototypes of design products.

Postsecondary design instruction emphasizes the creative elements of person, process, and product. Person refers to the individual student. Process refers to the methodology used by the student to develop the product, which is the outcome or end results of the process the student applied toward the design challenge (De La Harpe, Peterson, Frankham, Zehner, Neale, \& McDermott, 2009). The creative design process consists of steps used to effectively problem-solve through design challenges in order to arrive at appropriate solutions. Corcoran and Sim outline these steps as (1) factfinding, (2) idea-finding, (3) solution-finding, and (4) acceptance-finding (2009). Visual educators must teach design students how to move through these steps of the creative process. Teaching the creative process involves Problem-Based Learning (PBL) and 
Self-Regulatory Learning (SRL). Problem-Based Learning imparts the critical thinking and problem solving skills the student needs to learn to successfully navigate design challenges. Self-Regulatory Learning teaches the student, as stated by Zimmerman and Shunk, how to self-observe, self-judge and self-react so that they are active participants in their own learning process (1989). Traditionally, visual educators have taught PBL and SRL skills to design students in the studio-based environment.

Assessment of student developed products takes place in the form of critiques (or crits) in studio-based classrooms. Crits are oral presentations in which students display their design ideas, solutions, prototypes and products for feedback from peers and the instructor. Crits are the central place students learn what it means to be (and work) as design professionals (Dannels, 2005).

Crits serve as both an assessment and learning tool. Crits happen during the later "solution finding" phase of the design process. As a learning tool, crits support the visual learning method of teaching PBL and SRL skills. Designers must be able to successfully think-through and create solutions to design problems and then communicate their design concepts and solutions to clients, art directors and other designers on the job. Classroom crits allow postsecondary design students the opportunity to learn, adopt, and demonstrate professional ways of expressing their ideas. Design instructors can also use crits to assess how well students understand design instruction by how students present their products to the entire class during the crit. Collaboration occurs as students work with instructors and peers to visually assess the products and then to give comments and suggestions for next-steps for students to improve. 
The principles of cooperation affect most aspects of the graphic design field according to Chmela-Jones and Gaede (2007). Cooperative learning facilitates the collaboration that happens during the creative design process. Corcoran and Sim found cooperative learning methods to be most appreciated during the later solution finding stages of the design process and emphasize that a postsecondary cooperative learning design environment should stress collegiality, diversity and accountability (2009). PBL and SRL are maximized during crits while interpersonal interactions occur between the students and the teacher. These interactions support the "positive interdependence" needed for effective cooperative learning environments.

\section{Statement of the Issue}

Although traditional teacher-led, whole class critiques have been utilized for many years as a tool for both learning and assessment within design classrooms, there are some concerns with the crit process that threaten its level of effectiveness. First, there is the problem of instructors being too dominant in crits. Instructors that are not open to allowing students to express their own views can cause students to turn off to the critiquing process. Second, there is the issue of "lack of participation" from students in which students disengage and provide very little peer feedback. Third, there is a concern crits can be discouraging to students instead of encouraging. Students who are too emotionally attached to their work can find it difficult to receive negative feedback in front of the entire class if it is not delivered in a sensitive manner. Furthermore, students often withhold giving valuable critical feedback to peers out of fear of harming peers emotionally. Also, crits are problematic when students simply parrot back comments 
they hear from the instructor instead of making meaningful contributions to the dialogue themselves. They simply wait to be led by the faculty (Barrett, 2000).

Despite the numerous research studies in support of cooperative learning in adult education (Ahles \& Contento, 2006), there are many reasons why more graphic design instructors have not adopted its practice to enhance the effectiveness of their classroom critiques. First, they are more comfortable engaging in the traditional critique protocol with which they are more familiar. Second, there is more effort and work involved in integrating cooperative learning methods and monitoring groups during learning. It takes time to choose and implement appropriate structures and monitor groups so that students stay on task. Third, they would have to deal with the common cooperative learning problems of "hitch-hikers" and "bullies" within groups (Chmela-Jones \& Gaede, 2007). Group members could become frustrated and complain to instructors about those who are not pulling their weight during group work or those who want to dominate and control the group. The purpose of this study is to determine if the proper implementation of cooperative learning structures into the crit portion of the design instruction will impact the effectiveness of instruction as well as the overall crit experience for both students and instructor.

\section{Significance of the Study}

It is the aim of a conscientious design instructor to maximize the crit experience in the classroom by exploring ways and adopting pedagogy that will effectively address the assessment-focus of person, process and product. This study is important because it helps visual educators to identify ways they can more effectively incorporate cooperative learning methods into the crit portion of the design process. It is hoped that it will better 
equip visual educators to enable their students to take advantage of the proven benefits of cooperative learning. The intent of this study is to establish and verify effective cooperative learning structures and methodology for the studio-based design classroom.

The goal is for design instructors to feel more comfortable trying these methods to improve the effectiveness of instruction that takes place during critiques. Design instructors exposed only to the traditional teacher-led, whole-classroom critiquing styles are possibly unaware of other options. The study hopes to give them helpful options for conducting effective whole-classroom critiques.

\section{Biblical Integration}

When design instructors are in search of options and guidance with creating critique environments that fit within the parameters Dinham et al. (2007) suggest for constructing an effective visual education model, they can begin that search with the Bible. The Bible gives direction on how to build relationships of trust within group dynamics (such as those found in graphic design studio-based learning environments). In fact, the Bible explains how a leader (such as a design instructor) might humbly emulate the Holy Trinity to promote relationship-building that supports the principles of positive interdependence and individual accountability. As a result, the design instructor can both encourage the participation of and reap the benefits from the diverse individuals within the critique group setting. Furthermore, the three-personhood "small group" of the Holy Trinity is a model of how relationships within a harmonious small-group unit should function. The doctrine of the Holy Trinity exemplifies how relationships bring the needed components of unity and diversity to the world. Wayne Grudem (1999) explains in his book Bible Doctrine: Essential Teachings of the Christian Faith 
how the relationship between the personhoods of The Father, The Son and The Holy Spirit bring complimentary functionality within the small group of the Godhead. Each personhood within the Holy Trinity has a specifically unique and needed role to perform in relationship to each other and the world. And, although the roles are economically subordinate, the personhoods of each in the Trinity are ontologically equal. In other words, each member of the Holy Trinity is equal in being but subordinate in role. The doctrine of the Holy Trinity encourages people to relate to one another as the personhoods of the Godhead relate to one another -with unity, diversity, and mutual support.

The conscientious design instructor should note that the Bible promotes humility and associates it with grace and wisdom. However, the Bible discourages pride and associates it with disgrace (Proverbs 11:2, James 4:6, English Standard Version). The Bible teaches that those choosing to humble themselves will receive favor and exaltation from God (James 4:10, Luke 18:14, I Peter 5:6, Proverbs 3:34). For example, Moses is declared as one as the most humble men on earth in Chapter 12 of the book of Numbers. This self-imposed humility resulted in God exalting Moses to be feared and respected by both the Egyptians and the Israelites (Exodus 11:3, Exodus 14:30-31). Another example of self-imposed humility is seen in the Bible as Jesus empties himself of all the privileges of deity -taking on the form of a lowly human in order to serve mankind through his death on the cross. For this act of humility, God exalts Jesus to a position in which "every knee will bow" and "every tongue confess" that Jesus is Lord (Philippians 2:5-11). Also, the conscientious design instructor should note that Bible encourages leaders to be humble servants. Moses and Christ both model the biblical principle of 
humility in leadership. For example, Moses demonstrated humility in leadership as he laid aside his pride and insecurities concerning public speaking to serve the Israelites as God's mouthpiece in negotiations with Pharaoh (Exodus 4:10, 6:28-7:2, 7:6). Moses further demonstrated humility as he respectfully heeded the advice of his father-in-law to delegate some of the tasks and responsibilities to capable men that would help him bear the burden rather than attempting to address all the needs of the Israelite nation all on his own (Exodus 18:17-24).

Christ demonstrated humility in leadership as he washed the disciples' feet in an act of servitude toward them and then admonished them to do the same:

So when Jesus had washed their feet and put his outer clothing back on, he took his place at the table again and said to them, "Do you understand what I have done for you? You call me 'Teacher' and 'Lord' and do so correctly, for that is what I am. If I then, your Lord and Teacher, have washed your feet, you to ought to wash one another's feet. For I have given you an example-you should do just as I have done for you. I tell you the solemn truth, the slave is not greater than his master, nor is the one who is sent as a messenger greater than the one who sent him. (John 13: 12-17)

Jesus taught in word as well as deed the biblical principle for leaders to not see themselves as lofty authoritarians over those they lead, but instead see themselves as humble servants to them:

But Jesus called them and said, "You know that rulers of the Gentiles lord it over them, and those in high positions use their authority over them. It must not be this way among you! Instead, whoever wants to be great among you must be your 
servant, and whoever wants to be first among you must be your slave -just as the Son of Man did not come to be served but to serve, and to give his life as a ransom for many." (Matthew 20: 25-28)

The studious design educator should not overlook the fact that the Bible supports the concept of positive interdependence. This is demonstrated as the Bible instructs people to instruct one another (Colossians 3:16), bear one another's burdens (Galatians 6:2), confess faults to one another (James 5:16), and to encourage one another (1 Thessalonians 4:18). This concept is also demonstrated through the teachings on the body of Christ. The teachings encourage each person in the body of Christ to function as an eye or foot would as a member of the human body. Each member is admonished to equally value and respect the needed contribution of every other member. Also, each member is directed to suffer or rejoice along side its fellow members out of mutual concern for them (1 Corinthians 12:12-27).

Although the Bible clearly is in favor of individuals working harmoniously together for the benefit of one another, when structuring critique pedagogy, the attentive design educator should not overlook the fact that the Bible also supports the concept of individual accountability. The principle of individual accountability is seen biblically as each person will be required to give an account of himself to God (Romans 14:12). In fact, it states each person will give an account for every worthless word they speak (Matthew 12:36). Furthermore, leaders and teachers are particularly warned to be mindful of the account they must give as a person in authority who will be judged more strictly than others (Hẹbrews 13:17, James 3:1, Luke 17:2). 


\section{Chapter II: Review of the Literature}

\section{The Critique Experience}

Defined. In a study conducted by Dannels (2005) on design studio critiques, critiques are broken down into different types and distinguishing features of crits are noted. The desk crit is a type of crit in which the teacher and one individual student have a private discussion concerning the student's work. The teacher gives the student feedback and advice as they are working on the project. The pin up is a type of crit in which the student work is displayed on a large wall or board to receive feedback from the teacher as well as other students. This type of crit occurs in a more public fashion. The juries, crits, and reviews are types of crits that occur in the middle or end of the project. These crits are more formal public presentations in which students orally present their work to the teacher, other students, and sometimes visiting professionals from the business community. The open house is a type of crit in which student work is publicly displayed, students stand next to their work, and invited guests are asked to come and give each student one-on-one feedback on the work displayed. This crit usually occurs at the end of a project or academic term and students may choose to display more than one project for feedback.

Dannels (2005) names the distinguishing features of a crit as the wall-models, drawings and simulations, and audience feedback. The wall describes the space in which the work is presented, the work that is presented in that space, and the manner in which the work is presented in the space. The audience feedback is a fundamental part of the crit process in that students learn how to both give and receive crucial information about their work. 
Purpose. The purpose of the critique experience for the student is to get feedback. Students use the feedback to gauge their success in meeting the design challenge proposed by the instructor. Students also use the experience to gain insight on how to improve their skills so that they may gain entrance into the exclusive club of professional designers. The purpose of the critique experience for instructors is to assess the level of understanding the students have of the objectives being taught through instruction. The instructors also intend for the critique experience to produce an environment in which Problem-Based Learning (PBL) and Self-Regulated Learning (SRL) can effectively occur. Instructors aim for the activities of the critique experience to encourage students to engage in the higher-level thinking processes necessary for successful learning the creative design process.

Schön asserts that students can not be taught what they need to know in order to be effective professional practitioners, but instead must be coached and guided toward constructing their own self-understanding to be effective practitioners within their chosen field (Schön, 1987). Professor Gordon Salchow, appointed in 1968 by the University of Cincinnati to develop what is now known as their well-respected Department of Graphic Design, echoes this sentiment by stating that students can not be taught to be creative designers, but instead must be guided through an "investigative process" (G. R. Salchow, personal communication, October 20,2010). Salchow says:

It's not a matter of a student coming in [to art and design school] and just doing something correctly and having that be so creative [and] that it's going to be displayed on the refrigerator. They're past that stage! And, because of the mystique, I think, of art and design (visual art and design more so than other 
categories) there's a tendency for people coming into art and design school to think that it's about creativity. And, if they're gifted (and they've been told that they're gifted) they should just be able to do what they're capable of and be creative! And, it takes a while for them to understand that we're not trying to teach creativity and that they shouldn't try to be creative. What they're learning in design classes are the tools and the skills, and the knowledge. [We are] providing the knowledge base so that their creativity can be realized. Whatever creativity they have. (G. R. Salchow, personal communication, October 20, 2010) In his book Educating the Reflective Practitioner, Donald Schön (1987) discusses how design educators use the critique experience to teach "the design process" through reflection-in-action and reflection on reflection in action. Reflection-in-action is the concept Schön (1987) developed to describe a form of reflective "on-the-spot" thinking that occurs when a professional practitioner questions and evaluates how a current unexpected event resulted from a familiar action or routine that usually produces different results. The goal is for the reflection upon that unexpected event, as well as the actions that generated the event, to cause the professional practitioner to reshape his or her current actions to immediately address the situation at hand (Schön, 1987).

Reflection on reflection-in-action is the concept of the expert professional practitioner (i.e., the design instructor) assisting the novice professional practitioner (i.e., the design student) with reflection-in-action in order for the novice to accomplish much more than he or she could alone (Schön, 1987). The novice practitioner has limited professional knowledge with which to construct his or her own understanding for effectively addressing the situation at hand. Therefore, the novice needs the expert 
to scaffold (or support) his or her understanding between what the novice already knows and what the novice does not yet know in order for learning to occur during the reflection-in-action process. The crit scenario allows the experienced design instructor to guide the novice design student toward developing his or her own reflection-in-action skills specifically applicable to the creative design process used within the design profession.

Culture. The crit environment consists of a socialization process that begins to construct the student's professional identity as a designer. Crit environments in the design community are almost tribal in nature as rituals, performance, and history are deeply imbedded in its culture (Dannels, 2005). The culture of the critique experience consists of codes of behavior and rituals through which design students must navigate like a "rite of passage" into an exclusive club. It is described as a hazing ritual during which it is likely to hear students say, "It was a firing line! We were crucified! We were massacred! We were guillotined! We were led like sheep to slaughter! Our work was ripped to shreds!" (Anthony, 1991, p. 3). All participants in the critique have specific roles to play and rituals to observe. These roles and rituals are observed as participants move through the phases Popov (2007) defines as presenting, and critiquing.

During the presenting phase, students take on the role of presenter while the instructor and fellow students take on the role of audience. Like an actor on a theater stage, it is the duty of the presenter to give an oral presentation that the audience finds compelling and convincing. The design product of the presenter is displayed clearly for all to see. It is the job of the presenter to "sell" his or her design solution to the audience and to defend his or her reasoning for the solution. Like finicky high-society theater 
attendees, the audience determines if the work, presenter, and defense offered by the presenter are deemed "worthy" of acceptance.

During the critiquing phase, the audience reviews, evaluates, and judges the work of the presenter in the same way a movie critic reviews the latest movie release. It is the role of the audience, as led by the instructor, to give detailed oral response to the presenter concerning the reasoning for their acceptance, or rejection, of his or her work and oral defense. The comments of the instructor are sometimes laden with complex and confusing design jargon that the presenter is expected to understand. The culture promotes the ideal that the successful design professional belongs to an elite club that both understands and fluently speaks the complicated design language. If the presenter can neither understand nor fluently speak the language, it is assumed he or she is not yet worthy for membership into the club. More experienced and self-assured students within the audience population support this ritual by using design jargon whenever possible to not only validate their own acceptance into the club but to also challenge the admittance of the current presenter. Popov (2007) says critiquing is about professional initiation -"it is about delivering a verdict and allowing, accepting, and approving passage into the profession." (p. 55)

The highly performance-based environment created during the presenting and critiquing phases causes a great deal of stress and anxiety among students. Schön (1987) describes the creative design process as somewhat of an anxiety-producing learning paradox for design students because learning by doing throws design students into a situation in which they are asked to design -which is precisely the thing they not yet know how to do. However, in order to learn how to design, students must take a leap of 
faith that requires them to submit to the unfamiliar, and sometimes unnerving, culture of the critique process. Students must be willing to suspend disbelief that this unfamiliar learning process can inevitably teach them how to design. Submitting to "the process" of critique can produce anxiety in students because students fear they could lose their "sense of competence, control, and confidence" (p. 94) through submission to the process of learning to design. The crit experience challenges students to rethink and unlearn some of their current beliefs and understandings about art and design. Students must make a decision to loosen their grip on these current beliefs and understandings even if it causes them to temporarily doubt and/or lose confidence in their current abilities (Schön, 1987).

Professor Gordon Salchow, AIGA Fellow, experienced graphic design professor of 45 years, says instructors often like to "exercise muscle" during a critique (personal communication, October 20, 2010). Arrogant instructors embarrass and humiliate students to maintain their superior status in the elite club of design professionals. Students struggle to maintain their own dignity and respect among club members. Students aggressively fight verbally with one another as well as the instructor to retain any progress made in obtaining acceptance into the elite club. Schön (1987) warns, "If he [the student] comes [to the crit learning experience] with a distrust of those in authority, a readiness to see them as manipulating him, especially if he is unaware of his dispositions to perceive, then the willing suspension of disbelief may seem difficult or even impossible" (p. 95)

Popov (2007) defines the celebration phase as the final phase of the crit process. It occurs after the critiquing phase. The students and instructors take on more celebratory 
behavior, as the initiation process is now complete. Students and instructors perceive each other more as equals and celebrate their accomplishments. Students celebrate their survival of the initiation process and the completion of a lesson, project, or academic term. Instructors celebrate students demonstrating exceptional progress in learning design objectives. Classmates encourage and console each other. Sometimes the work evaluated during the critique experience is displayed publicly for family, friends and professionals from the design community to see. A reception, or celebratory food, is sometimes planned for this phase.

"Bad" Crits. Crowded large-group crits are among the worse crit scenarios. A study conducted by Blair (2006) concluded that large crits prevent the majority of students from giving feedback to peers and affect the quality of the learning experience. Also, students see large crit experiences as scary and confrontational. According to Parnell, Sara, Doidge, and Parsons (2007) in the worst crit scenarios, the crit is crowded and the students cannot see the work. Teachers talk only about their own interests. Teachers are aggressive and students are defensive. Students are often reduced to tears.

Students perceive a bad critique experience to be one in which little thoughtful feedback is given or the discussion promotes feelings of discouragement and anxiety. The nature of the critique culture is intimidating to some students. Students are reluctant to speak up and to fully participate if they think their ideas may be rejected or ridiculed. To reduce this risk, many students choose to instead withhold commenting. Any comments given tend to simply parrot-back whatever opinions were first verbalized by the instructor or more self-assured students. 
Arrogant instructors can dominate and control the critique experience. These instructors prefer to do most of the talking during a crit. They have unusually large egos and seek to be worshipped like charismatic politicians, religious leaders, or rock stars (Anthony, 1991). They also tend to intimidate and belittle students. Belittling behavior adds to the anxiety and discouragement students feel during critique experiences. Robert Probst, Dean of the College of Design, Architecture, Art and Planning at the University of Cincinnati (personal communication, November 19, 2010), says instructors act arrogantly to hide their own insecurities about the subject matter they are teaching. Dean Probst suggests instructors communicate honestly with students concerning their knowledge, or lack of knowledge, of the subject matter. The students will in return accept the instructor, his instructions, and respect the instructor for his or her honesty (R. Probst, personal communication, November 19, 2010).

Instructors also perceive a bad critique experience as one in which many students do not speak up and give feedback. Instead, students passively allow the instructor, along with a few self-assured students, to carry the full weight and responsibility for analyzing the work and giving constructive feedback (Barrett, 2000).

Instructors also perceive a bad crit experience as one in which the majority of students do not come with work to discuss that appropriately reflects the objectives of the lesson (G. R. Salchow, personal communication, October 20, 2010). When the work students present during a critique does not demonstrate a proper understanding of the material covered in class, it can suggest that the instructor did not adequately teach the material, the students did not have sufficient time to digest the material, or the assignment requirements were unrealistic or not clearly communicated. 
"Good" Crits. Students perceive a good critique experience to be one in which feedback is given that enables them to progress to the next steps in the learning process, motivates them to think critically and creatively, and encourages rather than belittles (Barrett, 2000). Students desire to know if they are appropriately applying principles taught in the classroom. Students appreciate and respect the feedback of classmates while ultimately looking to the instructor for final validation and acceptance. The manner in which the instructor imparts feedback, or allows students to impart feedback to one another during the critique, can enable students to leave the critique experience feeling encouraged with the validation they seek and a willingness to incorporate the constructive suggestions discussed. Students seek honest, thoughtful feedback that is delivered with respect and compassion.

Instructors perceive a good critique experience to be one in which the majority of students demonstrate a proper understanding of the design principles and learning objectives introduced in prior lessons. Instructors also perceive a good critique experience as one in which many students speak up and actively participate. Heller states in his book Teaching Graphic Design: Course Offerings and Class Projects From the Leading Undergraduate and Graduate Programs (2003) that it is an expectation in all critiques that students come prepared to present their concepts, how their designs support their concepts, and how they arrived at their ideas and designs.

Best Practices. Anthony calls for the reformation of the critique culture to eliminate the characteristics of it that include psychologically destructive and unethical behavior that comes from antagonism, fear, boredom, insensitivity, and competition. He says all these aspects contribute to unhealthy attitudes toward design practice 
(1991). Reformation initiatives take shape in endeavors such as creating a comfortable environment, allowing crits to be more student-centered and driven, and placing more focus on encouragement and learning.

A comfortable and laid-back critique environment encourages student participation during crits. Some students are more comfortable speaking in smaller groups, says Professor Gordon Salchow (personal communication, October 20, 2010), the 2002 recipient of the University of Cincinnati's Design Architecture, Art and Planning College's Outstanding Professor of The Year Award. Salchow also suggests games and tricks can lighten the mood and boost student involvement during crits. For example, Salchow sometimes played the design studio version of the game "spin the bottle." In Salchow's version, he spins a bottle on the floor. The bottle stops spinning and points at a student. That student is then chosen as the next to give feedback during the critique (G. R. Salchow, personal communication, October 20, 2010).

Dean Robert Probst was listed as one of The DesignIntelligence Most Admired Educators of 2010 for exemplifying excellence in design education leadership. Dean Probst (personal communication, November 19, 2010) suggests design instructors avoid the firing squad scenarios during critiques. Probst says he looks for the positive things the student has done on the project. He gives encouraging feedback on what the student has done correctly while avoiding negative comments on what the student has done poorly. Dean Probst says the students will respect the instructor more for showing compassion toward the low-performing student and not embarrassing him or her in front of the entire class during the critique (R. Probst, personal communication, November 19, 2010). 
Instructors act more like facilitators or coaches during a student-driven crit.

Students are encouraged to lead the discussion and to give comments before the instructor talks. The instructor validates the opinions of the students. The instructor does not insist his or her opinion is the only valid response. Barrett (2000) suggests the instructor act as a mentor stating, "Were students to know and feel that their instructors were trying to mentor them rather than criticize them, students would likely respond more positively to and engage more readily in critical discussions of their work." (p. 35)

According to Parnell et al. (2007) student-led crits boost the development of critical skills, team-working and communication skills. Not only do students enjoy student-led crits, but also student-led crits promote increased participation, enable students to share problems with others working on the same assignment, and are less boring.

\section{Cooperative Learning}

Defined. Cooperative learning is defined as an instructional method in which small groups are used to maximize student learning. Students work together in groups to accomplish shared goals (D. W. Johnson \& R. Johnson, 1999). Many teachers are realizing the gains in student learning by transitioning from centralized discourse, in which the majority of classroom dialogue stems from teacher leadership, to decentralized discourse, in which student-led discussions direct learning. This is because, as stated by John O'Flahavan, "Teachers who transfer social and interpretive autonomy to student groups often enjoy seeing their students experience higher-order understandings and richer interpersonal relationships." (1995, p. 356) Conversational Discussion Groups $(\mathrm{CDG})$ is an example of this approach to learning in which the teacher forms student 
groups of four to six students each for the purposes of allowing students to control their own social and interpretive paths to learning (Wiencek \& O'Flahavan, 1994). During these CDG structures teachers coach students both before and after students meet in groups. Also, teachers scaffold students during their group discussions (O'Flahavan, 1995). As a result, student-driven discussions of the instructional content direct the paths of learning rather than the teacher. Although groups are student-led, teachers must properly monitor and structure the activities for students so that chaos and misdirection does not occur during group work. Often many faculty members untrained in cooperative learning teaching methodology mistakenly think that cooperative learning is achieved by simply breaking the class into small groups to work on some shared task or assignment for which a group grade is collectively earned. However, several components need to be present within the lesson for it to function as a true cooperative learning lesson.

There is consensus among most experts that the two components of positive interdependence and individual accountability are necessary for a lesson to be categorized as cooperative learning (S. Kagan \& M. Kagan, 2009). Positive interdependence is the understanding among group members that each group member's efforts are required in order to learn the assigned material (D. W. Johnson \& R. Johnson, 1999). Individual accountability is the understanding among group members that each group member is personally responsible for his or her own contributions to the group work and no group member can get a free ride on the work of others. While experts David and Roger Johnson advocate the use of group grades, experts Spencer and Miguel Kagan see it "blatantly unfair" (p. 1.9) for students to receive grades based on the work 
performance, or lack there of, of teammates (2009). Instead, the Kagans (2009) support the practice of grading students on individual work -not group work.

The Kagans (2009) also add the components of equal participation and simultaneous interaction to qualify a lesson as cooperative learning. Equal participation occurs when the lesson is structured in a way that student participation within the group is distributed relatively equally. Simultaneous interaction occurs when the lesson is structured in a way that increases the active engagement of as many students within the classroom at the same time. Simultaneous interaction increases student engagement and participation while also saving classroom time (S. Kagan \& M. Kagan, 2009).

Proper formation of cooperative learning teams plays a critical role in the effectiveness of the cooperative learning lesson. Millis and Cottell (1998) report that most university and college instructors prefer heterogeneous groupings of four because students "tend to stay attentive and on task" (p. 50), are not able to "hide" within the large numbers, and groups are still able to "function smoothly when team members are occasionally absent" (p. 50). Aronson, Blaney, Stephan, Sikes, and Snapp (1978) say that it is ideal for groups to be diverse- containing students who are "boys and girls, assertive and nonassertive" (p. 36), of varying reading levels and personality types, and from different racial and ethnic groups. Ferguson-Patrick (2010) also expresses the importance of proper group formation when quoting a teacher during a study as saying:

When you structure the groups correctly it's like some students scaffold other students' learning, you know like if you sort of put same ability groups I don't think they'd get anywhere but you'll find that some students can pull other students up and support their learning and that sort of thing and it gives them a bit 
more confidence ...so I found that everyone just scaffolded each

other's learning (p. 396).

Structures. Cooperative learning structures are content-free teaching tools with which instructors build learning experiences. Structures are independent of any curriculum and therefore can be used repeatedly with many kinds of different subject matter. Spencer Kagan is the trailblazer of the structures approach. Over 200 Kagan Structures were developed and are used world-wide by tens of thousands of teachers to meet a variety of different learning objectives (S. Kagan \& M. Kagan, 2009). Kagan Structures (2009) encourage achievement and engagement as well as promote thinking and social skills. For example, the Round Robin All Write Consensus (p. 6.33) structure was designed to promote teambuilding, social skills, communication skills, decisionmaking, knowledge building, procedure learning and thinking skills. Also, the Round Robin All Write Consensus structure helps students to grow skills with presenting and processing information (S. Kagan \& M. Kagan, 2009).

The Team-Stand-N-Share (p. 6.37) structure was designed to aid students with social, communication, and knowledge building skills. Students also grow skills with presenting and processing information with the Team-Stand-N-Share structure. The Within Team Jigsaw (p. 17.3) structure aids students with presenting information and social skills. Also, the Within Team Jigsaw structure helps students to exercise their problem-solving and thinking skills. This structure also is designed to aid with procedure learning (S. Kagan \& M. Kagan, 2009). Millis and Cottell caution higher education teachers to ignore the "cutesy terminology" used to describe these structures because 
"The point is: cooperative learning works, call it what one will." (Millis \& Cottell, 1998, p. 69)

Higher Education. Cooperative learning is now considered the preferred instructional procedure at all levels of education and postsecondary educators all over the world are using it. Cooperative learning is beneficial in postsecondary education because it maximizes student learning -particularly the learning of difficult material of a higher complexity (D. W. Johnson, R. Johnson, \& Smith, 2007). Cooperative learning also prepares college students for interactions within a professional setting in which individuals must work together as a team to reached shared goals. In a college classroom setting, cooperative learning engages students in Problem-Based Learning (PBL) scenarios in which students must learn to manage emotions such as anger or frustration in order to meet the shared goals of the team (Attle, \& Baker, 2007).

Design. The concept of cooperation is heavily supported in design studio-based learning environments. In fact, Corcoran and Sim (2009) comment that the "flexible use of classroom space in Visual Art environments is conducive to cooperative learning." (p. 56). Within the design studio-based learning environment, teaching sessions are often structured in ways that encourage group discussions and interactions among students. For example, Raein reports in a 2004 study that Graphic Design program students were required to participate in a series of group seminars. During the group seminars students were asked to present proposals, results from information gathering activities, and results from the critical analysis done of information gathered. The developers of the Graphic Design program used the cooperative interactions during the group seminars to support their teaching objectives to: 
Locate discussions about the practice of design within appropriate critical perspectives such as the history, social sciences, linguistic, and communication theories; Enable students to create studio-based projects which reflect "deep learning"; Enable students to observe relationship between research and development of design strategies; and Facilitate a debate about the role of research, critical analysis and synthesis (p. 171).

Furthermore, Samantha Lawrie (2008), Associate Professor of Graphic Design at Auburn University, supports the concept of cooperation through encouraging graphic design educators to envision the profession functioning more cooperatively within communities. Because graphic designers play such an instrumental role in society as makers-ofmeaning, as communicators desiring to send a specific message to a predetermined audience through their work, Lawrie calls for graphic designers to be experts in shared experience -working to more thoroughly understand, through experience, the perspectives of those within the community to which designers desire their work communicate (Lawrie, 2008). In her article "Graphic Design: Can It Be Something More? Report on Research in Progress, "Lawrie says graphic designers should move beyond their previous role of aligning themselves mainly with the interests of business, and focus more on functioning as "facilitators of communication among myriad communities of people: not only between businesses and consumers, but also between communities of citizens, governments, scientists, scholars, activists and other social groups too numerous to list." (p. 206). Lawrie (2008) also says design educators should aspire that graphic design not merely be used as a component of "consumerist lifestyles" (p. 206), but more as a "mediator of balanced human relationships" (p. 206). 


\section{Action Research and the Experience Sampling Method}

Action Research. Action research is a practical and efficient way for educators to conduct research within their educational environment (Tomal, 2003). It is a collaborative approach that allows educators to work with colleagues and students to find solutions to problems. As the researcher, the educator collects and analyzes data with the main objective of discovering and implementing feasible solutions within the classroom context.

Experience Sampling Method. The experience sampling method (ESM) was developed by Csikszentmihalyi, Rathunde, and Whalen (1993) as a way of collecting data used to examine the quality of experiences during an activity. Csikszentmihalyi's flow theory (1990) claims that when participants are so intensely focused during a certain activity that they lose track of time and abandon irrelevant thoughts (Csikszentmihalyi, Rathunde, \& Whalen, 1993), the participants see that activity as challenging -and themselves as having the skills to meet that challenge. This optimal or quality experience is what teachers aim to create with learning activities -as to avoid the alternative of creating environments that inspire anxiety (high challenge with low skills), boredom (low challenge with high skill), or apathy (low challenge with low skill).

The experience sampling method examines optimal experiences through interrupting an activity to question participants about their perceptions of the experience. Participants complete a questionnaire that measures the cognitive, emotional, and motivational facets of consciousness within the context of the activity at hand. Csikszentmihalyi and Schneider used flow theory and ESM in a study (2000) concluding the combination of small-group work, tests, quizzes, and individual work brought 


\section{Action Research and the Experience Sampling Method}

Action Research. Action research is a practical and efficient way for educators to conduct research within their educational environment (Tomal, 2003). It is a collaborative approach that allows educators to work with colleagues and students to find solutions to problems. As the researcher, the educator collects and analyzes data with the main objective of discovering and implementing feasible solutions within the classroom context.

Experience Sampling Method. The experience sampling method (ESM) was developed by Csikszentmihalyi, Rathunde, and Whalen (1993) as a way of collecting data used to examine the quality of experiences during an activity. Csikszentmihalyi's flow theory (1990) claims that when participants are so intensely focused during a certain activity that they lose track of time and abandon irrelevant thoughts (Csikszentmihalyi, Rathunde, \& Whalen, 1993), the participants see that activity as challenging -and themselves as having the skills to meet that challenge. This optimal or quality experience is what teachers aim to create with learning activities - as to avoid the alternative of creating environments that inspire anxiety (high challenge with low skills), boredom (low challenge with high skill), or apathy (low challenge with low skill).

The experience sampling method examines optimal experiences through interrupting an activity to question participants about their perceptions of the experience. Participants complete a questionnaire that measures the cognitive, emotional, and motivational facets of consciousness within the context of the activity at hand. Csikszentmihalyi and Schneider used flow theory and ESM in a study (2000) concluding the combination of small-group work, tests, quizzes, and individual work brought 
about a higher quality of experience than listening to lectures and watching videos. Csikszentmihalyi and Schneider's study (2000) prompted Peterson and Miller to adopt the use of flow theory and ESM in a study comparing student experiences during largegroup and cooperative learning instruction (Peterson \& Miller, 2004).

Peterson and Miller (2004) used ESM in a study comparing the quality of college students' experiences during large-group and cooperative learning instruction. Student participants in the Peterson and Miller (2004) study "were significantly more likely to perceive relatively high levels of challenge and skill (ie., flow) during cooperative learning and relatively low levels of challenge and skill (ie., apathy) during large-group instruction." (p. 132). The increased opportunity to experience flow during cooperative learning is important, says Peterson and Miller (2004), because of the association flow has with "higher levels of concentration, enjoyment, happiness, strength, motivation, selfesteem, and perceived task importance among teenagers." (Csikszentmihalyi \& Schneider, 2000, p. 132). Furthermore, the Peterson and Miller study (2004) notes it significant that students perceived small-group discussions as more important to their future goals. Peterson and Miller borrowed heavily from Csikszentmihalyi's work (2000) to structure both the research questions and the data collection instruments in the 2004 study. This study follows Peterson and Miller's lead in adopting flow theory and the use of ESM to compare the quality of design-college students' experiences during largegroup and cooperative learning critique instruction. 


\section{Chapter III: Methodology and Procedures}

This action research study focuses on students' experiences during critiques when using cooperative learning methods and the overall effectiveness level of the crit as a result of the accurate implementation of cooperative learning methods.

Research Questions:

1. How do design students and instructors view critiques and the critiquing experience within the learning environments of the researcher's school?

2. How do design students' experiences during large-group, whole-class critiques compare to cooperative learning critique experiences on the cognitive, emotional, and motivational levels?

\section{Scope of the Study and Delimitations}

This study examined the impact of cooperative learning structures administered only during the critique phase of design instruction. The study did not address cooperative learning as it pertains to other phases of the creative design process because cooperative learning is already recognized as an important aspect of other parts of the studio-based design learning process. However design educators tend to overlook integrating cooperative learning methods into the typical whole-class crit. The study also did not address cooperative learning as it pertains to other styles of critiquing that may serve a purpose other than having students assess projects for learning throughout an ongoing course of instruction.

\section{Participants}

Student participants in this study were 36 first year visual communications undergraduate students attending a required 11-week foundational design course at 
Sinclair Community College, a community college in the Midwest. Student participants were enrolled in one of two sections of the course. Fourteen students were either absent during class sessions in which the data collection took place, or chose not to complete the questionnaires. These student participants were therefore excluded from the analyses. The final sampling of student participants was 22 . Faculty participants in the study were eight graphic design instructors at the same community college. Therefore, there were 30 total participants in this study (see Figure 1A).

\section{Course Information}

The 11-week design course was an introduction to the fundamentals of threedimensional design as they apply to visual communications, printing, and the arts (see Appendix A). Both instructors (one of whom was myself as the researcher) each taught a section of the course as adjuncts for the Visual Communications Department during the time of the study. Both instructors taught under the direction of the same full-time faculty member who served as a team captain for the course. As team captain for the course, the full-time faculty member provided the adjuncts with a master syllabus for the course (see Appendix A) along with a list of projects to be used by the adjuncts in teaching the course. The adjuncts were given the flexibility to choose the order in which the projects were taught as well as given the option to choose the methodology they deemed most appropriate for teaching the core objectives listed on the master syllabus for the course.

\section{The Classroom Setting}

Both sections conducted sessions in classrooms located next door to each other in the Visual Communications Department on Sinclair Community College's main campus. 
The main campus is located in the downtown, Dayton Ohio area. Sinclair Community College is driven by the mission to make high quality learning opportunities accessible and affordable so that individuals can turn dreams into achievable goals.

\section{Procedures and Data Collection}

I used surveys, questionnaires, and interviews to collect data. First, six faculty participants completed a survey with open-ended questions about critiques (see Appendix $\mathrm{B}$ and Figure 1B). The faculty participants were asked to complete the following five statements on the survey: "A critique is... The main objectives of critiques are... A good critique is when... A bad critique is when... Difficult aspects of critiques for me are..." The survey questions were the same questions used in a study conducted by Terry Barrett, a professor of art education at The Ohio State University. Barrett's study explored the thoughts and feelings of both instructors and students during critiques (2000). Only instructors were asked to complete all five statements in the Barrett study (2000) while students were additionally asked their perceptions of good and bad critiques. This study asked 22 student participants to complete the five statements in addition to asking the six faculty participants to complete the five statements (see Figure 1B).

Second, I used the experience sampling method to obtain student quality of experience data. Nine student participants (along with 11 non-participant classmates) received eight traditional whole-class critique sessions throughout the academic term (see Figure 1C). Each whole-class critique session lasted approximately two hours each. Seven participant students (along with seven non-participant classmates) received eight treatments of cooperative learning (see Figure 1C). Each cooperative learning critique session lasted approximately 75 minutes each. I named the cooperative learning 
treatment Design Structures. The Design Structures treatment was administered over eight separate crit sessions. Student participants in the traditional large-group, whole-
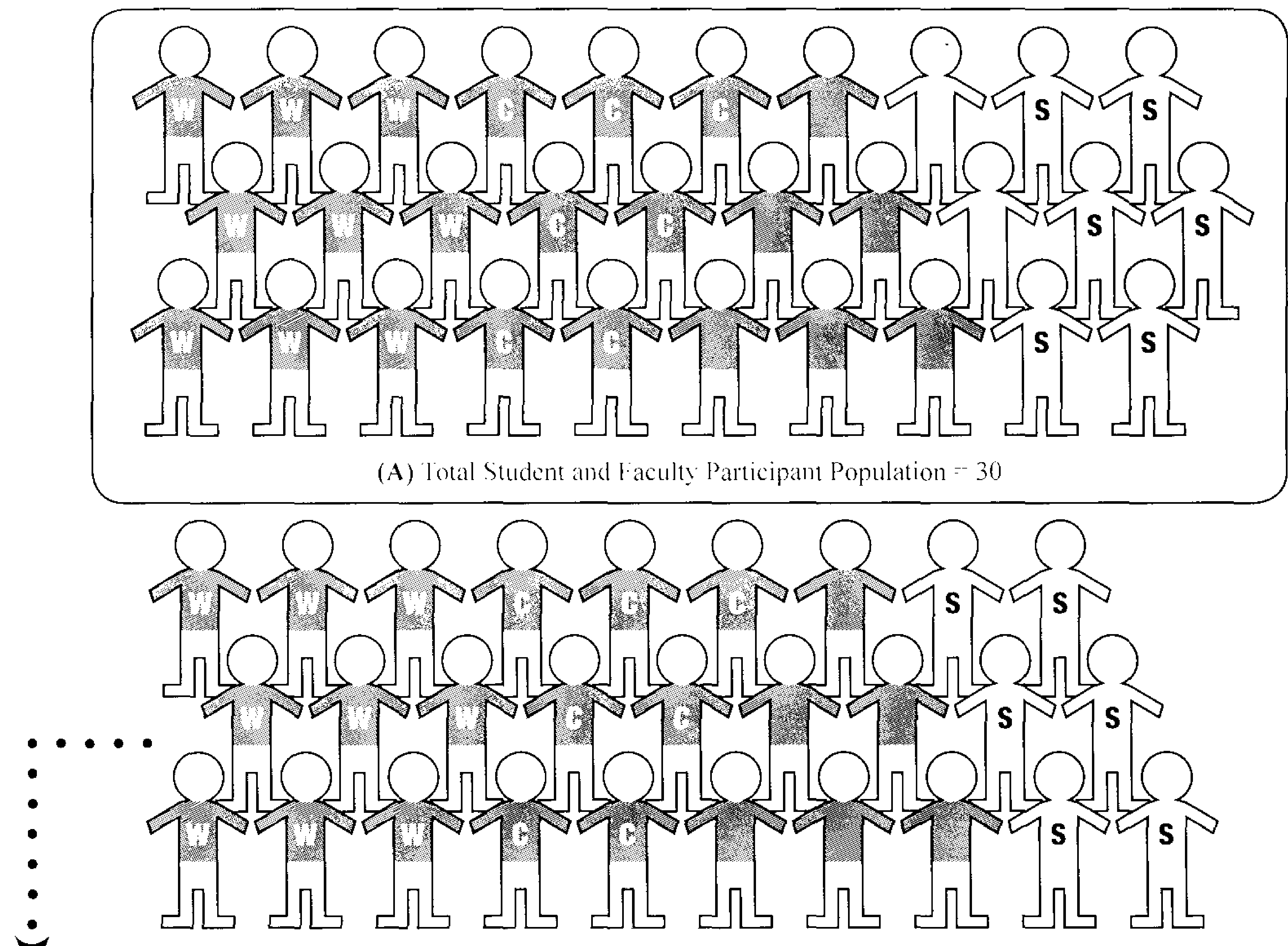

(B) Twenty Eight Student and laculty Participants Completed a Survey With Open-Ended Questions

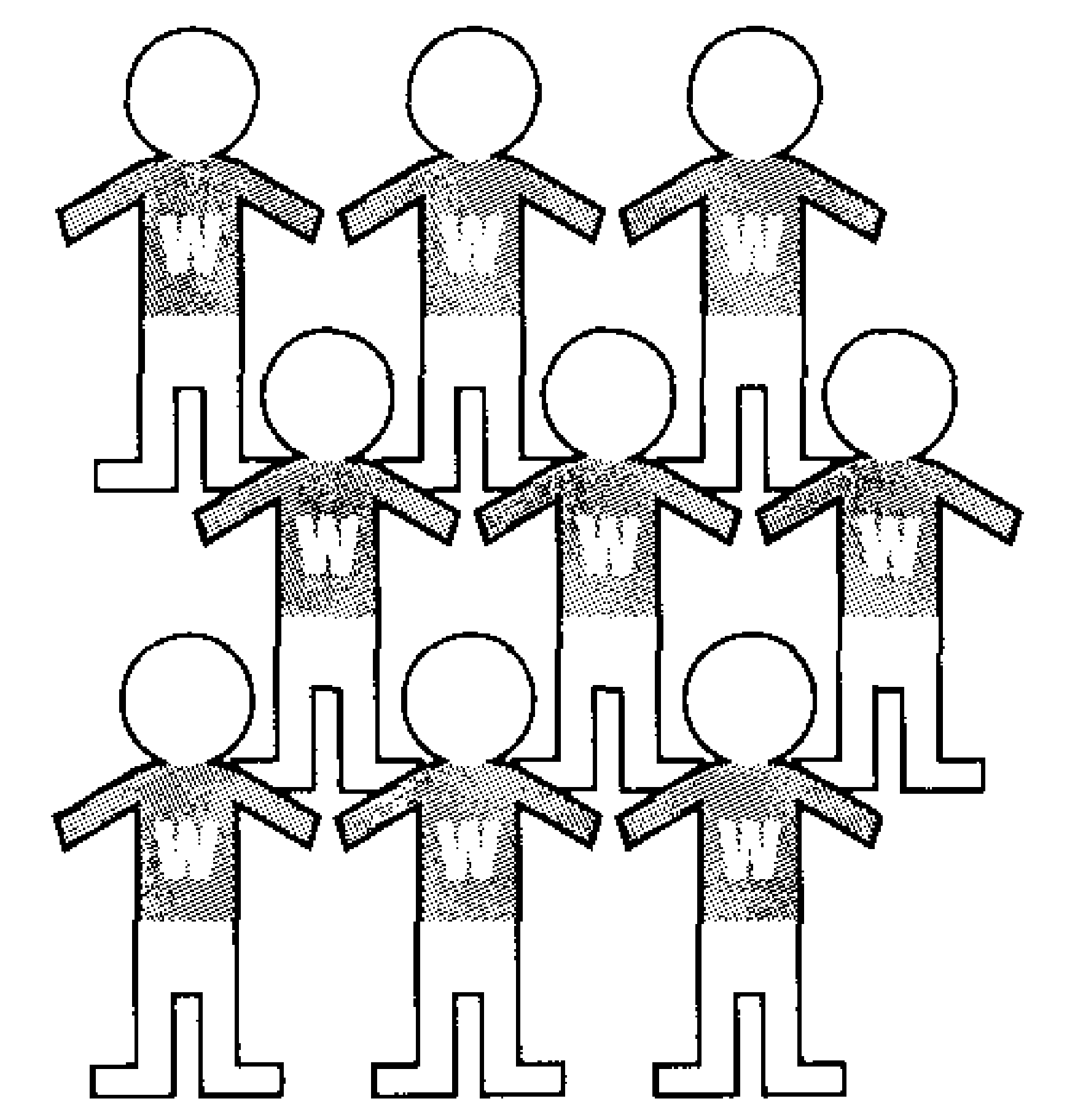

(C) Nine Whole-Class Crit Student Participants and Seven Cooperative Learning (Design Structures) Crit Student Participants Completed the ESM Questionnaires

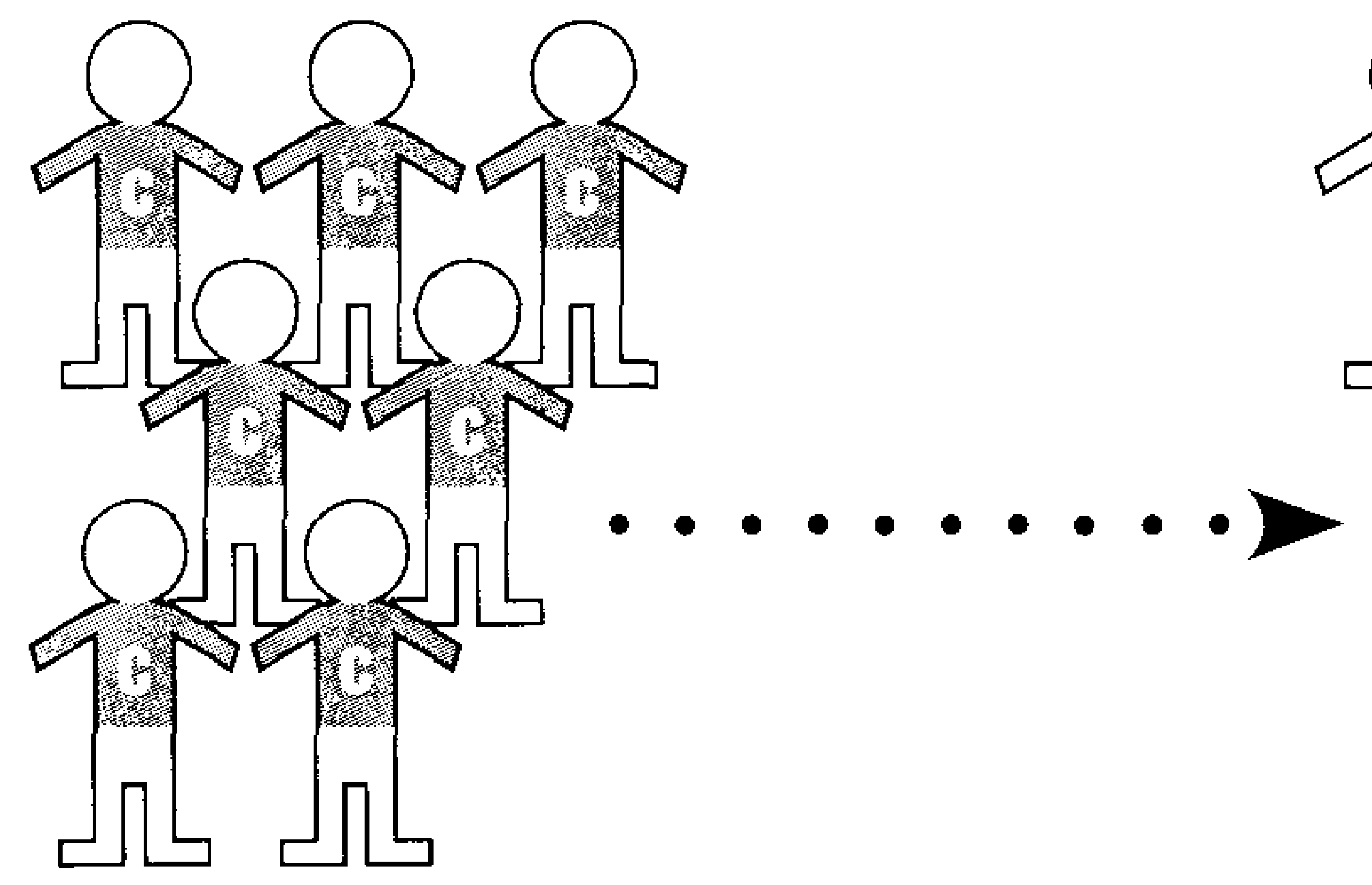

(D) Eight Faculty Participants Were Interviewed

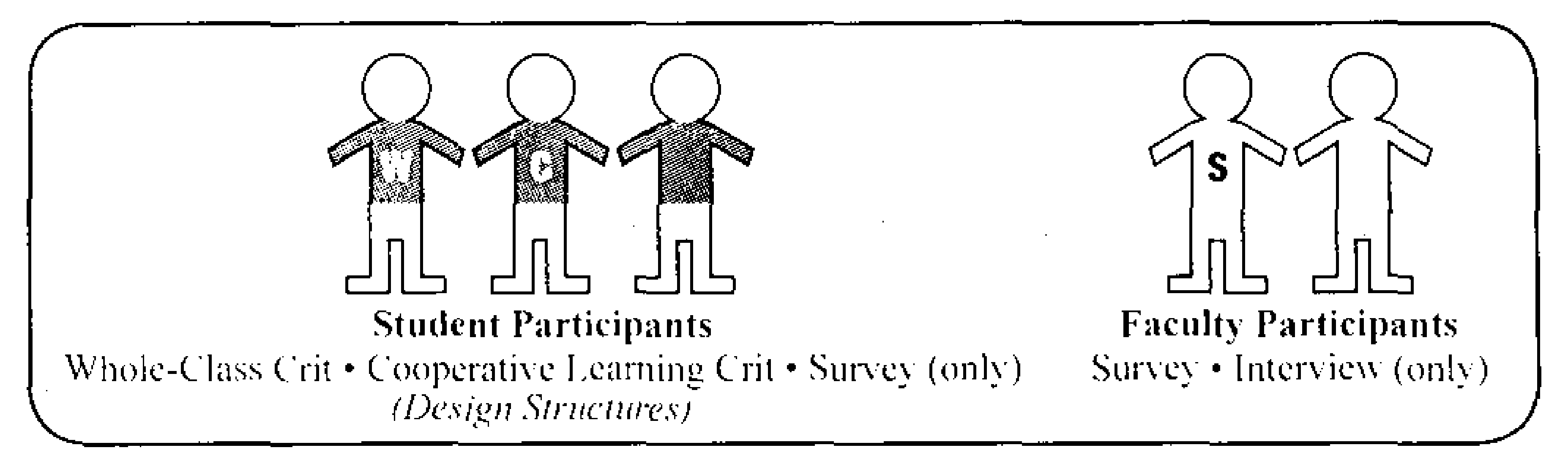

Figure 1. Details of Participant Population and Data Collection Sequence. Total design student and faculty participant population was 30 (A). First, 28 student and faculty participants completed the survey (B). Then, nine whole-class crit students and seven cooperative learning (Design Structures) crit students completed ESM questionnaires (C). Lastly, eight design faculty participants were interviewed (D). 
class critiques were interrupted during two whole-class critiquing sessions to complete an ESM questionnaire (see Appendix C and Figure 1C). Student participants in crit sessions receiving the Design Structures treatment were also interrupted during two of the eight treatment sessions to complete an ESM questionnaire. For both groupings of participants, the first interruption occurred during crit sessions scheduled for the seventh week of the course while the second interruption occurred during crit sessions scheduled for the eleventh week of the course. All four interruptions occurred 20 minutes after the start of that particular critique session. Lastly, I interviewed eight faculty participants to obtain faculty views on critiques and cooperative learning (see Appendix H and Figure 1D).

The ESM Questionnaire. The questionnaire used for this study was developed by Csikszentmihalyi et al. (1993). I chose this questionnaire to use for this study because Peterson and Miller used it successfully in a study comparing students' experiences during cooperative learning and large-group instruction (2004). The ESM is designed to measure the internal and external dimensions of experience. External dimensions of experience denote various life settings such as home, school or work, while internal dimensions refer to "emotional, cognitive, and motivational aspects of consciousness" (Csikzentmihalyi et al., 1993, p. 54). As with the Peterson and Miller study (2004), this study also does not look at the external dimensions because all participants were within the same setting. Only the internal cognitive, emotional, and motivational dimensions were explored.

\section{The Treatment: Design Structures}

Having graduate level instruction, and two years of professional experience, in the proper implementation of cooperative learning pedagogy, I developed variations 
of the Round Robin, the All Write Consensus, the Within Teams Jigsaw, and the TeamStand-N-Share cooperative learning Kagan (2009) structures to use as part of the Design Structures treatment. Before the start of each critique session, I heterogeneously grouped students into groups of four or five students per group. There were a total of four groups each crit session. I chose these amounts to allow for optimal cooperative learning effectiveness despite the occasional absent student or two from a group. I strategically and purposefully predetermined student groupings in advance of the critique. The groupings were a mixture of male and female students of various ages and races. I also purposefully comprised the groupings of introverted and extroverted students. I used previous observations of the students during classroom experiences throughout the past 5 weeks to determine which students were introverted or extroverted. At times, I strategically grouped together and placed a pair of chatty pals with more shy students to encourage more engagement and interaction from the more introverted students. Also, at times I strategically grouped chatty pals separately to encourage the chatty pals to build new relationships with other students to remain on task. I grouped students with learning challenges with students who excelled in or showed sensitivity to the specific challenges of the struggling student. I evenly distributed students prone to chronic absences or prone to arriving to crits with incomplete products among groups. I also evenly distributed students prone to excelling on assignments and arriving to crits with well-executed products among groups.

Students brought their completed products, or products-in-progress, to evaluate within the groups. In support of positive interdependence, I encouraged students with incomplete, incorrect, or missing products to still participate in the critique discussion. 
I affirmed that the input and feedback of all students were valuable and needed for everyone to learn and that the challenges struggling students experienced were great topics for students to explore during the critique discussions.

I assigned each student an individual grade for the final product submitted for grading in support of individual accountability. Final product grades were not group grades and were not tied to the performance, or lack of performance, of any other student within a group. I informed students that the final product grading occurred after the critique and completion of the lesson. I also informed students that information discussed during the critique could influence their performance and grade on future products as well as the current product.

In support of coaching and scaffolding, I read aloud a list of questions each group was asked to consider (see Appendices D \& F). Because the questions related to lesson objectives (see Appendices E \& G) concerning the design products I asked students to evaluate while in groups, I jump-started the group discussions by suggesting, aloud to the entire class, possible considerations each group could explore during the group discussion time. In support of proper instructor monitoring of cooperative groups, I traveled around to each group in the role of a coach and mentor. I coached and scaffolded students as needed by encouraging them to remain on task, standing near any off-track group, and asking questions to help students glean specific knowledge from the assigned questions if reflecting-in-action among group members appeared stalled.

Round Robin All Write Consensus. While in groups, I asked students to work together to develop answers to questions I posed concerning their design products. In support of positive interdependence, I gave each group only one copy of the questions 
so that students must share in order to complete the task. In support of PBL and SRL, the questions I posed to the students addressed specific lesson objectives they should understand more clearly by the end of the critique discussion. In support of simultaneous interaction, I gave groups approximately 15 to 20 minutes to develop answers while working simultaneously in their respective groups. To develop answers, students evaluated the design products and each student took a turn giving feedback to their group. As a group, the students determined the consensus for the answers to the questions I posed to them. Each student wrote down what the group discussed and decided.

Within Team Jigsaw. To support individual accountability, each group was responsible for answering only one of several questions posed to the class. Each question addressed a different design objective for the lesson. Within each group, each student was individually responsible for reporting answers for only one aspect of the group's question. This dynamic encouraged equal participation. Each student wrote the group's consensus answer for that particular aspect of the question. Then, each student submitted his or her own hand-written notes of the consensus answer for a critique participation grade. In further support of individual accountability, I graded students independently on critique participation. The critique participation grade was based strictly on the individual student's physical presence during the critique activities, individual contribution during small-group discussion and presentations, and submission of the hand-written notes for that student's particular aspect of the group question.

Team-Stand-N-Share. After the 15 minutes of group PBL and SRL, the groups came back together as a class to discuss the findings of their assigned explorations. Each group took turns presenting to the class the consensus answers of their group. In 
support of equal participation, each group member took a turn presenting the aspect of the question for which he or she was responsible. In support of positive interdependence, each group member had to rely on the other group members to help develop an accurate consensus response for his or her aspect of the question that he or she would have to present to the class. Furthermore, positive interdependence was supported as each group needed to rely on the responses of other groups in order to learn the information pertaining to the other design objectives covered in those groups.

As a facilitator of this student-driven portion of the critique, I coached and scaffolded students by encouraging additional feedback and comments from the class as a whole as each group presented. I also corrected or redirected any incorrect student input presented in support of scaffolding and coaching. Additionally, I was careful to respectfully acknowledge and affirm all student comments and feedback as to reaffirm the student population that all student input was both valuable and needed for the learning of the entire class as a whole. After all groups finished presenting, I concluded the critique lesson with repeating and validating the information students discovered during the critique process and collected the hand-written notes for grading. 


\section{Chapter IV: Results}

\section{Bad Critique Perceptions}

Instructors in this study were asked to comment on bad critiques. Similarly to the study conducted by Barrett (2000), instructors in this study also identified students leaving a critique feeling discouraged or with hurt feelings as a problem. In fact $83 \%$ of faculty participants listed critiques that encourage discouragement or hurt feelings in students as problematic (see Table 1). One instructor responded that a bad critique is when "The individual being critiqued leaves feeling like she / he has been run over by a bus, will be changing majors and offers to sell their art supplies to anyone for five dollars." Another instructor responded that a bad critique is when "students take comments personally, become defensive, close their minds."

\section{Table 1}

Frequencies of Students 'and Instructors' Perceptions of Bad Critiques

\begin{tabular}{ccc}
\hline \multicolumn{1}{c}{ Dependent measure } & Instructors & Students \\
\hline $\begin{array}{c}\text { Discouragement and } \\
\text { hurt feelings }\end{array}$ & 5 & \\
$n$ & 83 & 45 \\
Lack of student & & \\
participation & & \\
& & \\
& 2 & 6 \\
No lcarning & 33 & 27 \\
(lack of corrective feedback) & & \\
$n$ & 3 & 12 \\
$\%$ & 50 & 55 \\
\hline
\end{tabular}

Note. $\%=$ percentage of total. Instructors $(N=6)$.

Students $(N=22)$. 
Just as with the Barrett (2000) study, faculty participants in this study (33\%) also identified lack of participation as problematic. One instructor noted, "A bad critique is when students are selfish and sleep or yawn or only participate in their own work. Only a few students regularly participate. Some don't even want to come up close to see the work, and you have to demand they come forward."

Faculty participants additionally identified critiques in which no learning occurs are problematic (see Table 1). Fifty percent of faculty participants listed lack of learning during critiques as an issue. For example, one instructor responded, "A bad critique is a subjective view of an artwork that does not encourage understanding or in some way discourages the creator to further their efforts." Another instructor indicated that students close their minds to learning when "students feel that what they did was perfect." The study conducted by Barrett (2000) did not note instructors identifying a lack of learning during critiques as a concern when asked to describe bad critiques.

Student participants were given surveys inquiring their perceptions of critiques during the fifth week of the course. All student participants had previous critique experience from a prerequisite two dimensional design basics course as well as the current three dimensional design basics course in which they were currently enrolled. Student participants in the Barrett (2000) study were asked about their negative critique experiences. Students responded similarly to instructors in identifying discouragement and hurt feelings as issues during critiques. In support of the findings in the Barrett (2000) study, $45 \%$ of student participants in this study also identified discouragement and hurt feelings as concerns when asked to describe bad critiques (see Table 1). One student responded that a bad critique is when "there is negativity or the 
sharing of ideas results in anger or hurt feelings." Another student responded that a bad critique is when "You attack the person, being rude, and not making good suggestions."

Students in the Barrett (2000) study also identified the lack of corrective feedback as part of a negative critique experience. Student participants in this study also identified the lack of corrective feedback as part of a negative critique experience (see Table 1). Students commented that no learning occurs when there is a lack of corrective feedback. One student responded that a bad critique is when "Someone just says 'oh that's good' or 'that's bad' and doesn't elaborate." Another student responded that a bad critique is when "[the critique experience] doesn't show the way to correct." Still, another student responded that a bad critique is when "no solution is reached, the person has gained nothing from the experience and is left in a no better or worse off state with a project."

Students in this study identified a lack of participation when asked to describe bad critiques (see Table 1). One student responded that a bad critique is when "No one gives input to the discussion." Another student responded, "The teacher does most of the talking, or the class doesn't feel comfortable enough with each other." Student participants in the Barrett (2000) study did not identify lack of participation as a concern when asked to describe bad critiques.

\section{Good Critique Perceptions}

When asked to comment on good critiques, similar to the study conducted by Barrett (2000), this study also reported instructors desiring cognitive content to come out of the critique experience. In fact $83 \%$ of faculty participants identified good critiques as ones in which learning occurs (see Table 2). One instructor responded that a good critique is when "constructive feedback is given to help the student during each design 
phase (they begin to speak the lingo)." Another instructor responded, "A good critique is an active discussion on a piece that encourages a deeper understanding of the artwork as well as a focus on a particular aspect of design." Still another instructor responded, "When the critique becomes a learning experience for me."

Just as with the study conducted by Barrett (2000), faculty participants in this study also identified that active participation is desired in a good critique experience. Fifty percent of faculty participants listed active participation as part of good critique (see Table 2). One instructor noted, "A good critique is when everyone participates." Another

Table 2

Frequencies of Students' and Instructors' Perceptions of Good Critiques

\begin{tabular}{lcc}
\hline \multicolumn{1}{c}{ Dependent measure } & Instructors & Students \\
\hline $\begin{array}{c}\text { Learning occurs } \\
\text { (cognitive content) }\end{array}$ & & \\
\multicolumn{1}{c}{$\%$} & 5 & 16 \\
Active student \\
participation
\end{tabular}

Note. $\%=$ percentage of total. Instructors $(N=6)$.

Students $(N=22)$. 
instructor responded, "A good critique is when the most people participate and humor happens."

Also, as with the study conducted by Barrett (2000) faculty participants in this study identified a good critique as emotionally positive -encouraging enthusiasm for art. Thirty-three percent of faculty participants indicated that good critiques are an emotionally positive experience (see Table 2). For example, one instructor responded, "A good critique is when students feel empowered / free to give feedback". Another instructor responded that a good critique is when "objectives are met in a democratic environment, avoiding a negative atmosphere where students get a negative or nervous connotation to the critique and its process."

Student participants in the Barrett (2000) study were asked about their criteria for good critique experiences. Students responded similarly to instructors in identifying an emotionally positive critique experience as good. Barrett reports that the students, however, requested this component more frequently than instructors. This study found $27 \%$ of student participants identifying an emotionally positive critique as good (see Table 2). One student responded that a good critique is when "People share their thoughts with each other in a nice and respectful way."

Just as in the Barrett (2000) study, both student and faculty participants identified cognitive content as part of good critiques (see Table 2). For example, one student responded that a critique is good when, "All parties learn and are inspired." Another student responded that a good critique is when "You help the person you are critiquing, giving them good feedback, telling them what they should or shouldn't do for their project." Still, other students responded, "You learn something like a better design idea or 
a better way to do it" and "The student leaves with a better understanding of their work, processes, and how to improve, and / or what to keep doing."

Student participants additionally identified that critiques in which active participation occurs are good (see Table 2). One student responded that a good critique is when, "There is a lot of participation, and critiques take longer than expected." The study conducted by Barrett (2000) did not note students identifying active participation as a desired component when asked to describe good critiques.

\section{Difficult Aspects of Critiques}

Faculty participants in the Barrett (2000) study were asked to identify aspects of critiques they found personally difficult. Although Barrett (2000) did not report the findings on this specific question, Barrett did generally state that instructors identified lack of participation and students leaving critiques feeling discouraged and defeated as areas of difficulty. Sixty-seven percent of faculty participants in this study did specifically identify encouraging student participation as a difficult aspect of critiques for them. One instructor responded, "Difficult aspects of critiques for me are engaging all of the students all of the time during a critique." Another instructor responded, "I have trouble with critiques when students refuse to participate."

Faculty participants in this study did specifically identify difficulty with giving criticism to students without students leaving the critique feeling discouraged and defeated. In fact, $33 \%$ of faculty participants identified this aspect as a difficulty for them. One instructor responded that difficult aspects of critiques for her were, "being careful to assure students won't be hurt, or take comments personally." Just as with the faculty participants, student participants in this study also listed difficulty with giving 
criticism to students without offending them. Forty-one percent of student participants listed giving criticism without offending as a difficult aspect of critiques for them personally. One student responded that difficult aspects of critiques for her were, "telling people if something looks like crap." Another student responded that difficult aspects were, "Giving constructive criticism. Being able to be honest about negative aspects without feeling bad." Still, another student responded, "I'm defensive and really try not to be. I have a hard time giving negative comments to people because I don't want them to take it personally like I would." The Barrett study (2000) did not report any findings of students struggling with giving criticism to other students without being offensive.

When asked to identify aspects of critiques that were personally difficult, $18 \%$ of student participants in this study reported difficulty with receiving criticism without becoming offended or discouraged. One student responded that difficult aspects of critiques for her were, "[the] self criticism that results. Improving my craft without taking a blow to self esteem." Another student responded, "To put your work on display in front of others and being humble enough to accept any and all criticism from peers." Although student participants in the Barrett study (2000) were not asked specifically to comment on personally difficult aspects of critiques, the study did note students' concerns with being emotionally hurt by critiques.

Both faculty and student participants in this study did specifically identify difficulty with effectively speaking and presenting to the class. In fact, $33 \%$ of faculty participants and $27 \%$ of student participants identified this aspect as a difficulty for them. One instructor responded that difficult aspects of critiques for her were, "making sure that what I am saying is clear and understood." One student responded, "talking in a large 
group" while another responded, "wording what I want to say before everyone moves on." The Barrett study (2000) did not report any findings of students nor instructors struggling with effectively communicating ideas to the class.

\section{Quality of Experience Comparisons}

As with the Peterson and Miller study (2004), responses were coded to the openended question: "What were you thinking about when you were interrupted?" from the ESM questionnaires. Responses were coded as on-task, related-to-task, and off-task. Students were coded as on-task if their response coincided with the specific learning activity occurring during the interruptions. For example, one student during one of the whole-class interruptions was coded as on-task with a response of "Ann's birdhouse" because Ann was the student presenting her serial-planes birdhouse structure to the entire class during that interruption. A student during one of the Design Structures (cooperative learning) critique interruptions was coded as on-task with a response of "adding more to my project" because students were evaluating their grid structure projects within their groups and discussing ways each student could make improvements. Students were coded as related-to-task with responses that were not specifically concerning the ongoing learning activity, but showed their thinking was still related to learning skills associated

with the design process in some way. Students were coded off-task if their response showed their thinking was neither related to the learning activity at hand nor the design process in any way.

As with the student participants in the Peterson and Miller study (2004), there was no statistically significant difference between students in this study who were thinking about something on-task during cooperative learning and students who were thinking 
Table 3

Frequencies of Students' Thoughts Across Instructional Context

\begin{tabular}{|c|c|c|c|c|}
\hline \multirow[b]{2}{*}{ Dependent measure } & \multicolumn{2}{|c|}{ First interruption } & \multicolumn{2}{|c|}{ Second interruption } \\
\hline & Class crit & Coop crit & Class crit & Coop crit \\
\hline \multicolumn{5}{|l|}{ On task } \\
\hline$n$ & 3 & 3 & 2 & 2 \\
\hline$\%$ & 33 & 43 & 22 & 29 \\
\hline \multicolumn{5}{|l|}{ Related to task } \\
\hline$n$ & 5 & 3 & 4 & 0 \\
\hline$\%$ & 56 & 43 & 44 & 0 \\
\hline \multicolumn{5}{|l|}{ Off task } \\
\hline$n$ & 1 & 1 & 3 & 5 \\
\hline$\%$ & 11 & 14 & 33 & 71 \\
\hline
\end{tabular}

Note. $\%=$ percentage of total. Whole class crit $(N=9)$. Cooperative learning crit $(N=$ 7). Adapted from "Comparing the Quality of Students' Experiences During Cooperative Learning and Large-Group Instruction" by S. Peterson, and J. Miller, 2004. The Journal of Educational Research, 3, p. 128.

about something on-task during whole class instruction. During the first interruptions, $33 \%$ of whole-class critique participants were on-task while $43 \%$ of Design Structures critique participants were on-task (see Table 3). During the second interruptions, 22\% of whole-class critique participants were on-task while $29 \%$ of Design Structures participants were on-task. Peterson and Miller (2004) combined on-task and relatedto-task responses to find a statistically significant difference between the combined on-task and related-to-task responses versus off-task responses -in favor of cooperative learning. I did not find similar results when comparing the combined on-task and relatedto-task responses to the off-task responses. During the first interruptions, $89 \%$ of wholeclass critique participants were either on-task or related to task while $86 \%$ of Design Structures critique participants were either on-task or related-to-task. During the second interruptions, $66 \%$ of whole-class critique participants were either on-task or related-totask while only $29 \%$ of Design Structures participants either on-task or related-to-task. 
Because the interruptions occurred approximately 20 minutes after the crit sessions started, more Design Structures participants were possibly off-task during the second interruption because they were transitioning from Round Robin All Write Consensus work to Team-Stand-N-Share work.

Peterson and Miller performed repeated measures multivariate analysis of variance (MANOVA) to analyze Likert-type and semantic differential data items from the ESM questionnaires of their 2004 study. However, because of the small sample sizes, I used independent sample $t$ tests in this study to analyze the Likert-type and semantic differential data items comparing student cognitive, emotional, and motivational facets of consciousness during whole-class and Design Structures critique activities. The maximum score for cognitive efficiency, perceived learning, self-esteem, importance of task, intrinsic motivation, perceived control, challenge, and skill was 9. The maximum score for affective tone activation / potency, and degree of engagement was 7. Some of the Likert-type and semantic differential data items were recoded so that the maximum scores for all items represented the most favorable (or highest quality) experience.

When examining the cognitive dimension, Peterson and Miller reported statistically significant results for cognitive efficiency with student participants in large-group instruction reporting a higher level of cognitive efficiency than students in cooperative learning instruction (2004). I did not find statistically significant results for cognitive efficiency in this study, $t(6)=0.13, p=0.45$ [first interruption], $t(6)=0.01$, $p=0.49$ [second interruption]. I also did not find statistically significant results for perceived learning in this study, $t(6)=0.27, p=0.39$ [first interruption], $t(6)=0.48, p$ 
$=0.32$ [second interruption]. However, the large-group participants in this study did show higher levels for perceived learning on the item "How much were you learning?" with both interruptions of the whole-class critique reporting higher levels than the Design Structures (cooperative learning) critiques. Means (with standard deviations in parentheses) for the first interruption were $6.89(1.76)$ for the whole-class crit and 6.29 (2.14) for the Design Structures crit. Means for the second interruption were 7.56 (1.33) for the whole-class crit and 6.29 (2.06) for the Design Structures crit. Unlike Peterson and Miller (2004), the cooperative learning participants in this study showed higher levels for quality of experience on the item "How self-conscious were you?" with both interruptions of the Design Structures critique participants reporting higher levels than the whole-class critique participants. Means for the first interruption were $4.56(1.88)$ for the whole-class crit and 5.57 (2.64) for the Design Structures crit. Means for the second interruption were $6.00(2.65)$ for the whole-class crit and $7.14(1.86)$ for the Design Structures crit. Student participants in the Design Structures critique felt less selfconscious than student participants in the whole-class critique.

When examining the emotional dimension, Peterson and Miller (2004) reported no statistically significant results for affective tone, activation/potency, and self-esteem. I also found no statistically significant results for the emotional dimension in this study. For affective tone; $t(6)=0.30, p=0.38$ [first interruption], $t(6)=0.00, p=0.50$ [second interruption] were the conditions. For activation / potency; $t(6)=0.15, p=$ 0.44 [first interruption], $t(6)=0.06, p=0.48$ [second interruption] were the conditions. For self-esteem; $t(6)=0.03, p=0.49$ [first interruption], $t(6)=0.12, p=0.45$ [second interruption] were the conditions. However, Design Structures critique participants 
Table 4

Descriptive Statistics for Quality of Experience Variables

\begin{tabular}{|c|c|c|c|c|c|c|c|c|}
\hline \multirow[b]{3}{*}{ Dependent measure } & \multicolumn{4}{|c|}{ First interruption } & \multicolumn{4}{|c|}{ Second interruption } \\
\hline & \multicolumn{2}{|c|}{ Class crit } & \multicolumn{2}{|c|}{ Coop crit } & \multicolumn{2}{|c|}{ Class crit } & \multicolumn{2}{|c|}{ Coop crit } \\
\hline & $M$ & $S D$ & $M$ & $S D$ & $M$ & $S D$ & $M$ & $S D$ \\
\hline Cognitive efficiency & 5.50 & 2.05 & 5.64 & 2.34 & 6.28 & 1.98 & 5.32 & 2.29 \\
\hline Perceived learning & 6.89 & 1.76 & 6.29 & 2.14 & 7.56 & 1.33 & 6.29 & 2.06 \\
\hline Affective tone & 5.00 & 1.24 & 5.19 & 1.25 & 5.41 & 2.42 & 4.90 & 1.16 \\
\hline Activation/potency & 4.64 & 1.55 & 4.25 & 1.43 & 4.92 & 1.61 & 4.50 & 2.02 \\
\hline Self-esteem & 6.13 & 1.65 & 6.80 & 1.49 & 6.18 & 2.41 & 7.83 & 1.26 \\
\hline Degree of engagement & 5.28 & 1.23 & 4.93 & 1.49 & 5.28 & 2.90 & 5.57 & 2.43 \\
\hline Importance of task & 6.00 & 2.11 & 6.62 & 1.96 & 6.56 & 1.97 & 7.00 & 1.79 \\
\hline Intrinsic motivation & 4.89 & 3.06 & 8.00 & 0.82 & 4.22 & 3.15 & 7.00 & 1.29 \\
\hline Perceived control & 5.22 & 2.54 & 6.00 & 2.89 & 7.00 & 1.41 & 6.00 & 2.08 \\
\hline Challenge & 5.00 & 2.18 & 6.57 & 1.72 & 5.22 & 1.72 & 6.14 & 1.95 \\
\hline Skill & 5.22 & 2.39 & 5.86 & 1.68 & 5.78 & 2.33 & 7.29 & 1.70 \\
\hline
\end{tabular}

Note. Maximum score for cognitive efficiency, perceived learning, self-esteem, importance of task, intrinsic motivation, perceived control, challenge, and skill $=9$; maximum score for affective tone, activation/potency, and degree of engagement $=7$. Adapted from "Comparing the Quality of Students' Experiences During Cooperative Learning and Large-Group Instruction" by S. Peterson, and J. Miller, 2004. The Journal of Educational Research, 3, p. 128.

in this study did report higher levels of self-esteem during both interruptions than participants in the whole-class critiques (see Table 4). Means for the first interruption were 6.13 (1.65) for the whole-class crit and 6.80 (1.49) for the Design Structures crit. Means for the second interruption were 6.18 (2.41) for the whole-class crit and 7.83 (1.26) for the Design Structures crit.

Students in the Design Structures critiques consistently reported higher quality of experience levels than students in the whole-class critiques during both interruptions of several self-esteem items. For example, on the item "Did you feel good about yourself?" means for the first interruption were $6.33(1.73)$ for the whole-class crit and $6.71(1.70)$ 
for the Design Structures crit, while means for the second interruption were 6.67 (2.29) for the whole-class crit and $8.14(0.69)$ for the Design Structures crit. On the item "Were you living up to your own expectations?" means for the first interruption were 5.89 (1.96) for the whole-class crit and 7.29 (1.38) for the Design Structures crit, while means for the second interruption were $6.00(2.78)$ for the whole-class crit and $7.86(1.35)$ for the Design Structures crit. On the item "Were you succeeding at what you were doing?" means for the first interruption were $6.22(1.64)$ for the whole-class crit and $6.86(1.21)$ for the Design Structures crit, while means for the second interruption were 6.56 (1.81) for the whole-class crit and 8.00 (1.00) for the Design Structures crit. Peterson and Miller comment in their 2004 study that although they did not find a statistically significant result for self-esteem, Slavin (1995) cited multiple studies showing the positive impact of cooperative learning on self-esteem. Therefore the findings on self-esteem in this study seem to coincide with previous studies -implying larger sample sizes in this study would have most likely yielded statistically significant differences in self-esteem in favor of cooperative learning.

When examining the motivational dimension, Peterson and Miller (2004) reported statistically significant results for degree of engagement, perceived importance of the task, and challenge with student participants in cooperative learning groups reporting higher level than students in large-group instruction. I did not find statistically significant results for motivational dimension due to small sample sizes in this study. For degree of engagement; $t(6)=0.24, p=0.40$ [first interruption], $t(6)=0.31, p=0.38$ [second interruption] were the conditions. For perceived importance of task; $t(6)=0.16, p=$ 0.44 [first interruption], $t(6)=0.17, p=0.43$ [second interruption] were the conditions. 
For challenge; $t(6)=0.07, p=0.47$ [first interruption], $t(6)=0.17, p=0.44$ [second interruption] were the conditions. However, Design Structures (cooperative learning) critique participants in this study did report higher levels of perceived importance of the task, challenge, and skill during both interruptions than participants in the whole-class critiques (see Table 4). These findings suggest that larger sample sizes in this study would have most likely provided statistically significant differences in the motivational dimension favoring cooperative learning.

When examining the relative levels of challenge and skill, Peterson and Miller (2004) reported statistically significant results in favor of cooperative learning. I did not find statistically significant results for the relative levels of challenge and skill, $t(6)=$

Table 5

Frequency of Flow Groups Across Instructional Context

\begin{tabular}{|c|c|c|c|c|c|}
\hline \multirow{2}{*}{\multicolumn{2}{|c|}{ Dependent measure }} & \multicolumn{2}{|c|}{ First interruption } & \multicolumn{2}{|c|}{ Second interruption } \\
\hline & & Class crit & Coop crit & Class crit & Coop crit \\
\hline \multicolumn{6}{|c|}{ Flow } \\
\hline & $n$ & 3 & 5 & 5 & 5 \\
\hline & $\%$ & 33 & 71 & 56 & 71 \\
\hline \multicolumn{6}{|c|}{ Anxiety } \\
\hline & $n$ & 1 & 1 & 1 & 1 \\
\hline & $\%$ & 11 & 14 & 11 & 14 \\
\hline \multicolumn{6}{|c|}{ Boredom } \\
\hline & $n$ & 4 & 1 & 2 & 1 \\
\hline & $\%$ & 44 & 14 & 22 & 14 \\
\hline \multicolumn{6}{|c|}{ Apathy } \\
\hline & $n$ & 1 & 0 & 1 & 0 \\
\hline & $\%$ & 11 & 0 & 11 & 0 \\
\hline
\end{tabular}

Note. $\%=$ percentage of total. Flow $=$ high challenge/high skill; anxiety $=$ high challenge/low skill; boredom $=$ low challenge/high skill; apathy $=$ low challenge/low skill. Whole class crit $(N=9)$. Cooperative learning crit $(N=7)$. Adapted from "Comparing the Quality of Students' Experiences During Cooperative Learning and Large-Group Instruction" by S. Peterson, and J. Miller, 2004. The Journal of Educational Research, 3, p. 130. 
$0.32, p=0.38$ [first interruption], $t(6)=0.38, p=0.36$ [second interruption], due to small sample sizes in this study. However, similar to Peterson and Miller (2004), the participants in this study also showed more students were in flow and less apathetic during cooperative learning than large group instruction (see Table 5). In fact, both interruptions consistently produced results verifying that more students were in flow and less apathetic during Design Structures critiques than whole-class critiques. As with the Peterson and Miller study (2004), relative levels of challenge and skill in this study were examined through categorizing student participants and labeling the groups as flow, anxiety, boredom and apathy.

Table 5 shows the frequency data of relative levels of challenge and skill groups for both interruptions. During the first interruption, $33 \%$ of whole-class critique participants were in flow while $71 \%$ of Design Structures (cooperative learning) critique participants were in flow. During the second interruption, $56 \%$ of whole-class critique participants were in flow while $71 \%$ of Design Structures critique participants were in flow. During the first interruption, $11 \%$ of whole-class critique participants were in apathy while $0 \%$ of Design Structures critique participants were in apathy. During the second interruption, $11 \%$ of whole-class critique participants were in apathy while $0 \%$ of Design Structures critique participants were in apathy. The consistency of these findings throughout both interruptions suggest that larger sample sizes in this study would have most likely provided statistically significant differences in the relative levels of challenge and skill showing cooperative learning produced more students in flow and less in apathy during critiques than whole-class teacher-led critique instruction.

\section{Faculty Practices and Attitudes}


Data analysis of surveys showed that student and faculty participants expressed concerns with both student participation and students getting hurt feelings during critiques. Therefore, interviews with faculty participants focused on inquiring how instructors were currently addressing concerns about participation and hurt feelings. Faculty interviews also focused on instructor knowledge of cooperative learning techniques, structures, and benefits. Additionally, faculty interviews aimed to discover faculty apprehensions with and openness to implementing cooperative learning during their classroom critiques.

Most faculty participants used a very similar technique of "calling on students" to encourage student participation during critiques. When faculty participants were asked during interviews how they currently encourage student participation one faculty member responded, "I will call on people by name. [Also, sometimes ignoring students who dominate participation] and say 'Anyone else? We need to hear more opinions.' " Another responded, "The only thing that I've found is to just call them out." Still another faculty participant responded, "A lot of them don't like to speak. And, I just put them on the spot and make them tell us what they think of the design work."

Many faculty participants graded student participation as a means of encouragement. One faculty commented, "I would give critique grades and tell them 'this is such and such percentage of your grade. If I don't hear from you, your grade is going to suffer." Another instructor said, "It's part of a grade. So, that's always a built in incentive and motivation, most definitely, for them to participate."

Some faculty participants used specific activities to encourage student participation during critiques. For example, one faculty participant responded during the 
interview, "[I use] the trade-the-project technique. I break them up into groups of three and have them pass their projects to the left and have them look [at the project passed to them]. I have a list of things for them to discuss." Another instructor responded, "You kind of facilitate and ask for opinions that get them interested." This instructor further added, "Sometimes it's best to ask the participants [students who do not shy away from talking in front of the class] for information. You ask them for feedback. Sometimes they'll get the ball rolling. That helps."

Some faculty participants mentioned asking specific questions to encourage student participation. For example, one instructor commented during the interview, "I kind of give them some questions of what my expectations are. In a critique setting, some guidelines, I think, is really important in a successful critique. Otherwise, you're just going to get a whole lot of 'oh hums' and a whole lot of quiet." This faculty member further added, "Sometimes, everybody writing certain things before anything is said, I found, has been helpful. I'll throw a question out, 'What do you guys think about the flow of the website or their typography?'So I'm trying to use some of the design principles so that they're able to write that information down. 'Now let's discuss it.' Then, I give time to discuss."

Most faculty participants also used a very similar technique of "explaining the purpose up-front" to address student concerns about hurt feelings during critiques. When interviewed, faculty participants were asked how they currently address student concerns about hurt feelings during critiques, one faculty member responded, "That's something that's addressed up-front [in the course] when we first start the critique process. I go over with them, that it is not necessarily a place to bash work, that everyone's here to learn. 
It's a learning process." Another instructor responded, "It's part of what I say at the very beginning. That in this industry, that's what it's all about. The only way that you can get better and to learn is through critiquing. So this is a positive thing. It's not negative. It has nothing to do with you personally. What we're trying to do is to better your design skills." And, still another instructor commented that she explains to the students "You have to be able to support what you're doing rationally. You have to have reasons to explain to your art director, to your client, to the creative director, and to other designers. So, you have to know the terminology. And this is the place for you to wade into those waters and learn how to do that and not get your feelings hurt."

Many faculty participants also encouraged students to not take feedback personally. One interviewed instructor commented, "I mention to them that critiquing is not a personal thing [saying] 'They're not critiquing you as a person but they are just talking about the image that they are looking at. You shouldn't take it personally.' Although people do that." Another instructor responded, "I do always tell them that it's not a personal attack on people. It's just giving good advice on what the work is about. So, it's not about hurting people's feelings." Still, another instructor responded, "If they want to get into a shouting match or something, then I'm just like, 'Look. That's not what we're here for! We're trying to be constructive with this critique. So, whatever anger you have toward me or whoever said what... No! Unacceptable!' And, I just go over the rules again."

Many faculty participants commented that they stress the importance of wording feedback professionally, using design terminology, in their attempts to address student concerns about hurt feelings during critiques. These interviewed instructors said that they 
are careful about wording feedback appropriately and aim to set the example for students to follow. One instructor said, "I'm very careful with my words. I think that leads as an example to other students that, that is a way they can speak." Another instructor responded, "I make sure students, when they are giving feedback, that they give it in that manner, [strictly discussing the principles and elements of design] and if they really stick to the principles and elements of design and [talk] strictly about that, then that tends to help."

Some instructors commented that they sympathize with their students. To address student concerns about hurt feelings, some instructors strive to create a critique environment that is comforting to the student. One interviewed instructor commented that she tries to run a relaxed classroom. She added that she wants students to say, "I feel comfortable here" and find her classroom a less intimidating place "to have discussions about somebody's artwork." This instructor also added that she incorporated affirmations like, "What a good question!" or "What a good point!" into her feedback to create a more relaxed atmosphere. She further added, "Affirmations are a lot more powerful than we give them credit for." This instructor also commented that she believed her own recent experiences as a student influenced her to be more empathetic with her own students. Another instructor said he often uses humor as a tool to make the crit environment more relaxed. He also said he cracks jokes or shares funny videos with the students to lighten the mood.

When faculty participants were asked how familiar they were with the concept of cooperative learning, $75 \%$ of interviewed faculty participants claimed familiarity with the concept of cooperative learning. One instructor responded, "It's learning from other 
students versus the instructor. And, then they build relationships inside those cooperative learning groups." Another instructor responded, "I sat in on a couple of sessions that Sinclair had with people talking about cooperative learning, breaking up in smaller groups, and letting them [students] lead their own packs, so to speak, with me just walking around, listening, perhaps guiding if I see it's kind of going off."

Although $75 \%$ of interviewed faculty participants claimed familiarity with the concept of cooperative learning, several of their responses exposed their confusion in the understanding of the concept. For example, one instructor remarked, "Is there a difference between collaborative and cooperative?" He further added, "This is a policy at Sinclair. This is something that every institution, not just Sinclair, but across the country, is really pushing - collaborative learning. They're pushing cooperative learning. You can call it any buzz word you want." When another instructor was asked to comment on her familiarity with the concept of cooperative learning, she commented, "So when the students are working we, as instructors, we're contributing to what they're doing, [so are] the other students next to them during the critique. So, it's all a collaborative thing. You say cooperative. I say collaborative. To me, it means the same thing."

Interviewed faculty participants were asked to describe any cooperative learning structures with which they were familiar along with how it worked. Only $25 \%$ of faculty participants could name a specific cooperative learning structure. Although $25 \%$ of faculty participants could describe how a specific cooperative learning structure worked, only one faculty participant could give the specific name of the structure described. Nonetheless, $38 \%$ of faculty member participants remarked that they were implementing cooperative learning during critiques. When one instructor was asked if she was aware of 
any cooperative learning structures, she responded, "No, But, I'm sure that if somebody were to follow me for a quarter, or whatever it is, they would say I'm doing 'these, these, and these' - I don't understand them as 'that is a specific terminology." "She further added, "So, I couldn't reel-off to you the names of it, but I'm sure I'm doing it."

Because the responses of $88 \%$ of the interviewed faculty participants expressed either their confusion about or no knowledge of the concept of cooperative learning, faculty participants were asked specifically if they ever break a class into small groups during critiques. Seventy-five percent of faculty participants commented that they do occasionally break a class into small groups during critiques. In fact, $75 \%$ of faculty participants commented that there are benefits to breaking the students into small groups during critiques.

When asked to describe the benefits of breaking the class into small groups during critiques, interviewed faculty participants named increased relationship-building, increased trust-level, increased student participation, and increased learning as benefits. On the topic of relationship-building, one instructor responded, "It builds relationships. So if they have additional questions or other questions, or if they're at home at 2:00 in the morning working on a project, they can call one of their associates that they've been dealing with all quarter." Another instructor commented, "It also gets them to interact. That's the other thing that I've found. They don't know each other." She further adds, "For me, even if they're complaining about the class or me, it's great because then they have some sort of bond."

On the topic of increased trust-level as a benefit of small group critiques, one interviewed instructor responded, "I think that [critiquing in small groups] really goes 
a long way to boosting the level of trust among the students. So, I think they might get more [out of the critique experience] with a heightened level of trust or honesty. [Students will] just be more forthcoming and open to bringing up what the critical issues [are] that sometimes they don't when they haven't really bonded with the group and feel that level of trust." He further added, "I think that level of trust that you get from a learning community is probably the biggest strength in my guess."

On the topic of increased participation as a benefit of small group critiques, one interviewed instructor commented, "What I found is that those students who aren't comfortable telling the whole class what they think someone else can improve on their design, are much more comfortable in a small group. So, you actually get much more participation." Another instructor responded, "You can't hide behind five or six people. You might be able to hide behind 18." Yet another instructor remarked that when students critique in small groups, "They get a lot more chatty and a lot more animated. If they're talking in front of the whole group of students, they don't."

On the topic of increased learning as a benefit of small group critiques, one interviewed instructor responded, "When [the learning] was more cooperative... I think they learned it better." Another instructor commented, "[Students] gain a better understanding when it comes to their design understanding." Yet, another instructor remarked, "Everyone gets involved and it becomes very collaborative. The four students or the five students actually go to solve the problem versus just talking about what the other student created."

Although, $75 \%$ of interviewed faculty participants commented that there are benefits to breaking the students into small groups during critiques, $75 \%$ of faculty 
participants interviewed also expressed some apprehensions to breaking students into small groups during critiques. When asked to describe the apprehensions to breaking the class into small groups during critiques, interviewed faculty participants named missed opportunities for learning and the increased time and effort needed to adopt a new critiquing method as apprehensions to breaking students into small groups during critiques.

On the topic of missed opportunities for learning as a concern when breaking students into small groups during critiques, one interviewed instructor remarked, "When you break them up into groups like that, the only sad thing is that if you leave it at that, then the rest of the class doesn't necessarily get to see what else was done if they have an interest." Another instructor commented, "Small group critiques can not make up for full class critiques in my opinion." This instructor further added, "You're not getting the benefit of everybody in class. They will only get the benefit of whoever [is in] the group they're with." Yet another instructor remarked, "I'd rather have more minds looking at one piece of work than having just five people looking at a piece of work. You're missing out then on all these other cultural aspects that these other students could be giving opinions on. And so for me, then what's the point if we're not getting all those opinions?"

On the topic of the additional time and effort needed to adopt a new critiquing method as a concern when breaking students into small groups during critiques, one interviewed instructor remarked, "Just not wanting to administratively put the time in to make it all happen because it's different. It's easy to do the same old thing you've been doing rather than try something new." Another instructor responded, "It's a time issue. I 
don't see that I can add another type of critique. Period. Because there's no way I would substitute small critique for the big one. The big one is simply too valuable. Granted, there are those [students] who don't participate and maybe they would participate in a small group. I know that. But, it just feels like a crunch to get through everything. It's a struggle. It's my struggle."

When asked to describe the apprehensions to breaking the class into small groups during critiques, $25 \%$ of interviewed faculty participants additionally voiced a concern with keeping students on task when they are working in groups. Furthermore, one faculty participant voiced a concern with strong group members leading others astray when that strong group member incorrectly thinks that what he or she is doing is correct. Additionally, this same instructor voiced a concern with students in small groups tending to not delve deeply enough when discussing the work if the instructor is not right there to guide them down deeper paths of thought.

Although $75 \%$ of faculty participants interviewed expressed some apprehensions to breaking students into small groups during critiques, $100 \%$ of faculty participants interviewed commented that they would be open to learning how to properly implement cooperative learning during design critiques. When asked if he would be open to incorporating cooperative learning during his critiques, one instructor answered, "Sure! Absolutely! But at the same time, I feel like I'm really good at critiquing the students. I feel like I've had twenty-something years of experience working with these students." Another instructor commented, "I would be interested to learn about it." This instructor further added that it needed to be explained to faculty in the context of how it can be applied in a design classroom. 


\section{Chapter V: Summary}

\section{Conclusions}

In conclusion, this study was designed to establish and verify effective cooperative learning structures and methodology for the studio-based design classroom so that design instructors would feel more comfortable trying these methods to improve the effectiveness of instruction that takes place during critiques. The results imply that properly administering the cooperative learning treatment Design Structures to undergraduate graphic design students can contribute to higher levels of motivation, higher levels of self esteem, increased perceived importance of tasks, and higher levels of challenge as it relates to skill. Furthermore, the results suggest that students are more readily able to achieve flow and less apathetic during critiques when the instructor is adequately trained in and amply experienced with the proper implementation of cooperative learning methods.

\section{Discussion}

The results suggest that although many faculty participants in this environment claimed familiarity with the concept of cooperative learning, and some even assumed that they were already implementing cooperative learning during their critiques, most did not know much about any official cooperative learning techniques or structures. Faculty were aware that their learning institution, along with many others, encourages faculty to incorporate cooperative learning as a part of the teaching strategy because of the welldocumented success of the method. However, results suggest there is confusion among faculty concerning what learning activities truly qualify as cooperative learning activities 
and also concerning if true cooperative learning activities are appropriate for whole-class design critique situations.

Many assumptions are plausible when evaluating results that seem to favor whole-class critiques over cooperative learning critiques. For example, students may have reported feeling happier in whole-class critiques because they can more easily avoid participation through hiding within the larger number of students. Furthermore, students may have reported feeling more anxiety in cooperative learning critiques because of the increased responsibility for the learning of self and others that was created through the "individual accountability" dynamic of cooperative learning. This is a more positive and mature anxiety, or heightened alertness, resulting from the student's enhanced "in flow" engagement during the reflection on reflection-in-action portion of the critique learning process. An educator should find this positive anxiety a more desirable state for students than the alternative of a negative state of restfulness associated with boredom and apathy.

Furthermore, there are plausible assumptions when evaluating results showing students perceived they learned more during whole-class critiques than during cooperative learning critiques. As novices, students feel dependent upon the expertise and leadership of the instructor while learning the creative design process through reflection-in-action. During decentralized group-learning, students perhaps feel further removed from the guidance of the expert than during teacher-led whole-class crit situations. Therefore; the novice design student máy view himself or herself, as well as peers within his or her small group, as less competent to generate a meaningful crit learning experience without constant guidance and input from the instructor. As a result, students perceive they are learning less in the small-group cooperative learning setting. 


\section{Recommendations}

The implication for graphic design educators in the Sinclair Community College Visual Communications environment is that the implementation of the Design Structures treatment promotes the active and meaningful student participation that both students and faculty members want during critiques. Because the Design Structures treatment consists of cooperative learning activities that are purposefully structured to specifically help design students achieve their future goals, faculty members that choose to integrate the Design Structures treatment into their critique pedagogy can expect to see their students engage more in the critique learning experience.

Therefore, I recommend that the Visual Communications Department of Sinclair Community College adequately train design faculty in how to properly implement Design Structures cooperative learning methodology within a design critique environment. Training should include strategies for proper group formation, proper instructor monitoring of groups, and proper configuration of structures to ensure the primary cooperative learning components of positive interdependence and individually accountability are supported. Furthermore, training that additionally includes guidance on how to support the cooperative learning components of equal participation and simultaneous interaction is recommended to further increase the effectiveness and efficiency of cooperative learning methodology used during crits. Training should span beyond one in-service professional development day in order for faculty to thoroughly learn and officially adopt the Design Structures teaching strategy as part of their instructional routine. Faculty, for example, should form collaborative coaching networks similar to those Wiencek and O'Flahavan (1994) suggested for coaching 
faculty implementing Conversational Discussion Groups within literature classrooms. Design faculty should commit to meeting regularly over the span of the academic year to collaborate during coaching workshops. Collaborative coaching workshops would allow faculty trained in and experienced with effective cooperative learning strategies to mentor and scaffold fellow faculty. Also, collaborative coaching workshops would allow design faculty to develop, adapt and share cooperative learning crit techniques with peers that are tested and proven effective within their own learning environment. Design faculty should meet one-on-one or in teams often to provide each other mutual support as they learn together how to transition from instructor-led to student-led crits through effectively incorporating Design Structures into the Sinclair Community College Visual Communications pedagogy.

Furthermore, more research is needed to explore ways to address the concerns that faculty have about "missed opportunities" for learning when students do not have full access to reflective discussions held in other small groups in which they were not participants. Additionally, future research should explore ways to help both students and instructors to understand and embrace the kinds of learning that take place during critiques in which instruction is more decentralized, and more student-driven. Also, future research should explore ways to ease student anxiety and boost student confidence in peer-to-peer learning when design students are challenged during reflection-in-action learning during crits. Research should develop coping strategies for novice design students struggling with limited guidance from the expert instructor during group work.

In terms of a broader application to all graphic design and visual communication educators, the results suggest that the design educator seek to more humbly serve his 
or her student population during critique situations -as humility is key in leadership. Instructors that keep the focus on personal insecurities and strive to maintain their own personal comfort and status during the crit experience, invite intimidation, antagonism, fear, boredom, insensitivity and competition to creep into the critique experience. As Anthony (1991) warns, psychologically destructive or unethical behavior often results when these components enter into the crit experience. As a humble servant to the student, the design educator must realize that the need for the student to feel a sense of comfort and trust within the critique environment is paramount in maximizing learning during crits. Just as the self-imposed humility of Moses resulted in God exalting him to be respected by both the Egyptians and the Israelites (Exodus 11:3, Exodus 14:30-31), design students will respect and trust instructors who are humble. The Bible states that Jesus emptied himself of all the privileges of deity to serve mankind through his death on the cross (Philippians 2:5-11). Therefore, design instructors must make certain to empty themselves of pride to serve their students.

The students' needs must come before any personal reservations the design educator may have concerning the effort and time required to learn new teaching methods, the anxiety associated with parting ways with old teaching routines that are effortless to implement because of their second-nature familiarity, or insecurity associated with competition from young, innovative, junior-designers that are selfassured and eager to make room for themselves in the world of design.

The conscientious design educator should allow his or her redirected focus on humility to generate a more comforting crit atmosphere for the student that promotes positive interdependence. Positive interdependence is found in relationships based on 
unity, diversity, and mutual support. For the student, these relationships develop more easily in small group situations -exactly the kind of small group situations that are formulated during properly implemented cooperative learning pedagogy such as Design Structures. Therefore, design instructors should take a step back and play the role of a facilitator or mentor and simply coach, scaffold, and affirm students during critiques. Especially in situations where students come to crits with incomplete or "missing" products, design instructors should coach, scaffold, and affirm those students and include them in the crit process. As a result, students will learn to trust that the instructor still views them as valued and needed members of "the body" -the collective learning environment of their classroom. As the Bible tcaches, "The eye cannot say to the hand, 'I do not need you,' nor in turn can the head say to the foot, 'I do not need you.' On the contrary, those members that seem weaker are essential," (1 Corinthians 12:21-22). In closing, the design educator needs to allow the students to take more control and ownership of the critique learning process so that it is a less intimidating experience for students. Implementation of Design Structures gives design educators an opportunity to give some of the control and ownership of the crit back to the student. When the student trusts the critique environment is a safe place in which to share, more meaningful student participation and learning will occur during graphic design crits. 


\section{References}

Ahles, P., \& Contento, J. (2006). Explaining helping behavior in a cooperative learning classroom setting using attribution theory. Community College Journal of Research and Practice, 30, 609-626.

Anthony, K. (1991). Design juries on trial: The renaissance of the design studio. New York: Van Nostrand Reinhold.

Aronson, E., Blaney, N., Stephan, C., Sikes, J., \& Snapp, M. (1978). The Jigsaw Classroom. Beverly Hills: Sage Publications.

Attle, S., \& Baker, B. (2007). Cooperative learning in a competitive environment: Classroom applications. International Journal of Teaching and Learning in Higher Education, 19, 77-83.

Barrett, T. (2000). Studio critiques of student art: As they are, as they could be with mentoring. Theory Into Practice, 39, 29-35.

Chmela-Jones, K. A., Buys, C., \& Gaede, R. J. (2007). Visual learning and graphic design: A cooperative strategy. South African Journal of Higher Education, 21, 628-639.

Corcoran, K., \& Sim, C. (2009). Pedagogical reasoning, creativity and cooperative learning in the visual art classroom. International Journal of Education through Art, 5, 51-61.

Csikszentmihalyi, M. (1990). Flow: The psychology of optimal experience. New York: Harper \& Row.

Csikszentmihalyi, M., Rathunde, K.\& Whalen, S. (1993). Talented teenagers: The roots of success and failure. New York: Cambridge University Press. 
Csikszentmihalyi, M., \& Schneider, B. (2000). Becoming adult: How teenager's prepare for the world of work. New York: Basic Books.

Dannels, D. (2005). Performing tribal rituals: A genre analysis of "crits" in design studios. Communication Education, 54, 136-160.

De La Harpe, B., Peterson, J., Frankham, N., Zehner, R., Neale, D., Musgrave, E., \& McDermott, R. (2009). Assessment focus in studio: What is most prominent in architecture, art and design? International Journal of Art \& Design Education, 28, $37-51$.

Dinham, J., Grushka, K., MacCallum, J., Pascoe, R., Wright, P., \& Brown, N. (2007). Visual education - repositioning visual arts and design: Educating for expression and participation in an increasingly visually-mediated world. International Journal of Learning, 14, 77-85.

Ferguson-Patrick, K. (2010). Cooperative learning and quality teaching: Early career teachers striving for quality. The International Journal of Learning, 16, 385-400.

Grudem, W. (1999). Bible doctrine: Essential teachings of the Christian faith. Grand Rapids: Zondervan.

Heller, S. (2003). Teaching graphic design: Course offerings and class projects from the leading undergraduate and graduate programs. New York: Allworth Press.

Johnson, D. W., \& Johnson, R. (1999). Learning together and alone: Competitive, and individualistic learning. Needham Heights: Allyn \& Bacon.

Johnson, D. W., Johnson, R., \& Smith, K. (2007). The state of cooperative learning in postsecondary and professional settings. Educational Psychology Review, 19, 15 29. 
Kagan, S., \& Kagan, M. (2009). Kagan cooperative learning. San Clemente: Author.

Lawrie, S. (2008). Graphic design: Can it be something more? Report in progress. Art, Design \& Communication in Higher Education, 6, 201-207.

Millis, B. J., \& Cottell, P. G. (1998). Cooperative learning for higher education faculty. Westport: The Oryx Press.

O'Flahavan, J. F. (1995). Teacher role options in peer discussions about literature (National Reading Research Center). The Reading Teacher, 48, 354-356.

Parnell, R., Sara, R., Doidge, C., \& Parsons M. (2007). The crit: An architecture student's handbook (2nd ed.). Oxford, UK: Architectural Press.

Peterson, S. E., \& Miller, J. A. (2004). Comparing the quality of students' experiences during cooperative learning and large-group instruction. The Journal of Educational Research, 97, 123-133.

Raein, M. (2004). Integration of studio and theory in the teaching of graphic design. Art. Design \& Communication in Higher Education, 3, 163-174.

Schön, D. A. (1987). Educating the reflective practitioner: San Francisco: Jossey-Bass.

Slavin, R. E. (1995). Cooperative learning (2nd ed.). Boston: Allyn \& Bacon.

Tomal, D. (2003). Action research for educators. Lanham: The Scarecrow Press.

Wiencek, J., \& O’Flahavan, J. F. (1994). From teacher-led to peer discussions about literature: Suggestions for making the shift. Language Arts, 71, 488-498.

Zimmerman, B. J., \& Shunk, D. H. (1989). Self-regulated learning and academic achievement: Theory research, and practice. New York: Springer. 


\title{
Appendix A
}

\author{
Course Master Syllabus
}

VIS 107 Design Basics 3D

Sinclair Community College

Dayton, OH 45402

\section{Master Syllabus}

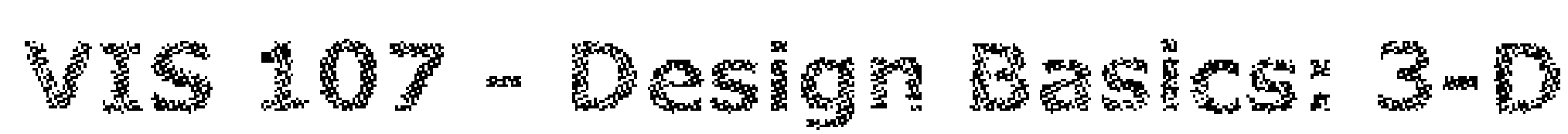

Division: Liberal Arts, Communication and Social Sciences

Department: Visual Communications

Credit Hour Total: 3.0

Lecture Hrs: 2.0 Lab Hrs: 4.0

Prerequisite(s): VIS 106

Date Revised: August 2007

\section{COUn日y}

Introduction to 3-D design fundamentals applied to visual communications, printing and the arts. Two lecture, four lab hours per week.

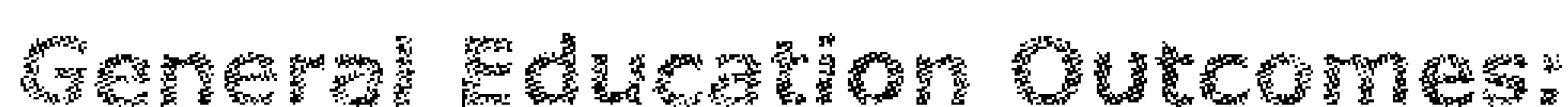

-1. Organize observable data into useful formats.

- Use appropriate problem-solving methods

Compose and deliver oral messages appropriate to an intended audience.

acknowledge diverse opinions, cultural and individual differences in communication interactions.

Exhibit openness to alternative ideas.

\section{Course Outcomes:}

Perspective and three-dimensional design

Exhibit knowledge of perspective and three-dimensional design.

Assessment Method: Portfolios

Performance Criteria: departmental average scores on first year assessment forms average 2.0 or better

\section{Current market trends}

Analyze current market trends.

Assessment Method: Performance appraisals

Performance Criteria: $70 \%$ of students correctly identify the demographics for their product

\section{Implement demographics}

Implement demographics, and how it is related to human behavior.

Assessment Method: Portfolios

Performance Criteria: $70 \%$ of students project designs correctly relate to theie chosen market

Elements and principles of design

Implement the use of elements and principles of design.

Assessment Method: Portfolios

Performance Criteria: departmental average scores on first year assessment forms average 2.0 or better

\section{Q10.}

3D design principles. Packaging. Point of purchase. Signage systems. 
Appendix B

Design Critique Survey

DESIGN CRITIQUE SURVEY

circle one: TEACHER / STUDENT

I would appreciate your answering the following 5 questions about critiques in design classrooms. Thanks for your participation!

1. A critique is...

2. The main objectives of critiques are...

3. A good critique is when...

4. A bad critique is when...

5. Difficult aspects of critiques for me are...

Adapted from "Studio Critiques of Student Art: As They Are, As They Could Be With Mentoring" by T. Barrett, 2000. Theory Into Practice, 39, p. 30. 
What were you thinking about when you were interrupted?:

Rate your response to the following questions:

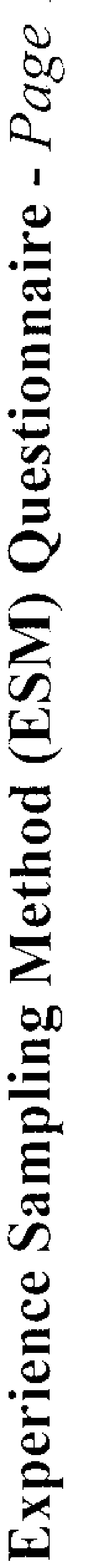

\section{When interrupted...}

not at some

all

some
what

quite

very

How well were you concentrating?

How hard was it to concentrate?

How self-conscious were you?

Were you in control of the situation?

Did you feel good about yourself?

Were you living up to your own expectations?

Were you living up to the expectations of others?

How much were you learning?

Describe your mood as you were interrupted:

very quite some neither some quite very

\begin{tabular}{|c|c|c|c|c|c|c|c|c|}
\hline alert & $\cdot$ & $\cdot$ & $\cdot$ & - & $\cdot$ & $\cdot$ & $\cdot$ & drowsy \\
\hline happy & $\cdot$ & $\cdot$ & $\cdot$ & - & $\cdot$ & $\cdot$ & $\cdot$ & sad \\
\hline irritable & $\cdot$ & $\cdot$ & $\cdot$ & - & $\cdot$ & $\cdot$ & $\cdot$ & cheerful \\
\hline strong & $\cdot$ & $\cdot$ & $\cdot$ & - & $\cdot$ & $\cdot$ & $\cdot$ & weak \\
\hline active & $\cdot$ & $\cdot$ & $\cdot$ & - & $\cdot$ & $\cdot$ & $\cdot$ & passive \\
\hline lonely & $\cdot$ & $\cdot$ & $\cdot$ & - & $\cdot$ & $\cdot$ & $\cdot$ & sociable \\
\hline involved & $\cdot$ & $\cdot$ & $\cdot$ & - & $\cdot$ & $\cdot$ & $\cdot$ & detatched \\
\hline excited & $\cdot$ & $\cdot$ & $\cdot$ & - & $\cdot$ & $\cdot$ & $\cdot$ & bored \\
\hline closed & $\cdot$ & $\cdot$ & $\cdot$ & - & $\cdot$ & $\cdot$ & $\cdot$ & open \\
\hline clear & $\cdot$ & $\cdot$ & $\cdot$ & - & $\cdot$ & $\cdot$ & $\cdot$ & confused \\
\hline
\end{tabular}

Z

o

चี

(2)

రृ $\sum_{2}^{\frac{\pi}{2}}$

$\exists$

$\frac{0}{\sigma} \dot{0}$

$\stackrel{\Xi}{\Xi}$

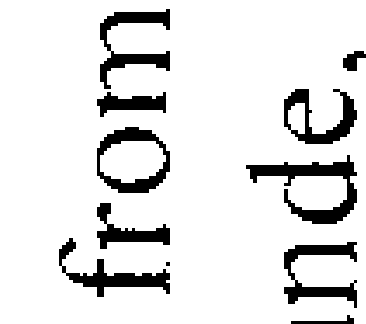

○

冚 
The challenges of the activity Your skills in the activity

\begin{tabular}{l|l|l|l}
0 & 1 & 2 & 3 \\
0 & 1 & 2 & 3
\end{tabular}

\begin{tabular}{l|l|l|}
4 & 5 \\
\hline & 4 & 5
\end{tabular}

\begin{tabular}{|l|l|l|l|l|l|}
\hline & 5 & 6 & 7 & 8 & 9 \\
\hline & 5 & 6 & 7 & 8 & 9 \\
\hline
\end{tabular}

not at

some

what

quite

very

\begin{tabular}{|l|c|c|c|c|c|c|c|c|c|c|}
\hline Was this activity important to you? & 0 & 1 & 2 & 3 & 4 & 5 & 6 & 7 & 8 & 9 \\
\hline Was this activity important to others? & 0 & 1 & 2 & 3 & 4 & 5 & 6 & 7 & 8 & 9 \\
\hline Were you succeeding at what you were doing? & 0 & 1 & 2 & 3 & 4 & 5 & 6 & 7 & 8 & 9 \\
\hline Do you wish you had been doing something else? & 0 & 1 & 2 & 3 & 4 & 5 & 6 & 7 & 8 & 9 \\
\hline Were you satisfied with how you were doing? & 0 & 1 & 2 & 3 & 4 & 5 & 6 & 7 & 8 & 9 \\
\hline How important was this activity in relation to your overall goals? & 0 & 1 & 2 & 3 & 4 & 5 & 6 & 7 & 8 & 9 \\
\hline
\end{tabular}

ה 
Appendix D

Round Robin All Write Consensus Questions -First Interruption

One of 4 groups was assigned either question-sections (1), (2), (3), or (4).

\section{CRITIQUE 5}

Get into groups (4 or 5 per group). As a group, discuss the following questions ( 2 - 3 minutes per question):

1) What were some common challenges you experienced when it came to deciding what YOUR repetition structure should look like? What were the different things people in your group did [their research \& brainstorming] to come up with ideas for this project? Have each person discuss THEIR process for deciding which idea was the most appropriate solution for this project. Who decided to build the very first idea they came up with (\& why)? Who did NOT construct their very first idea (\& why not)?

2) What were some common challenges you experienced using a grid effectively? Have each person explain how their creation is a repetition structure. For each person's project, list the unit forms that are repeating \& how a pattern was created. Choose 1 project \& explain to the class how it effectively uses the grid \& give advice for proper grid use.

3) What were some common challenges you experienced creating 3 dimensional visual excitement? Have each person explain how they created excitement with changes in shape, size, positioning, or edge treatments (bending, curling, angled cuts, etc). Choose the project your group finds the most exciting 3 dimensionally and explain to the class why it is? Share advice for building more 3D excitement into your structure.

4) What were some common challenges with craftsmanship? Explain how craftsmanship comes into play when placing unit forms within the grid (what happens when things are "off")? How do you keep the structure free of smudges, pencil marks \& extra glue? Which project has the best craftsmanship in your group (why?) 


\section{Appendix E}

\section{Project 5 Lesson Objectives -First Interruption}

Students could choose to complete (option \#1) the Form \& Structure with Grid product.

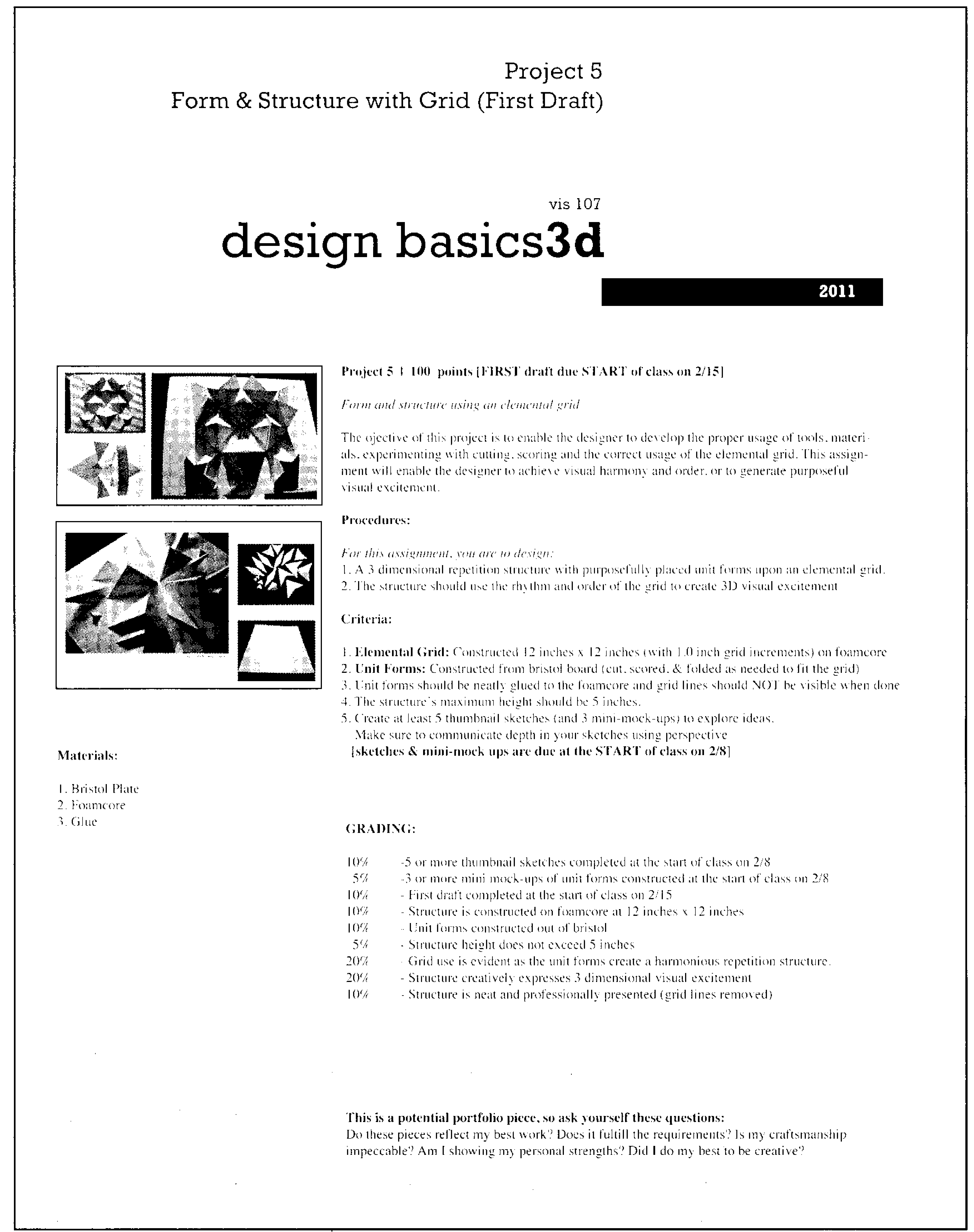

Adapted from Sinclair Community College [VIS 107 Grid Project Assignment Sheet] 
Students could choose to complete (option \#2) the Wall Structure product.

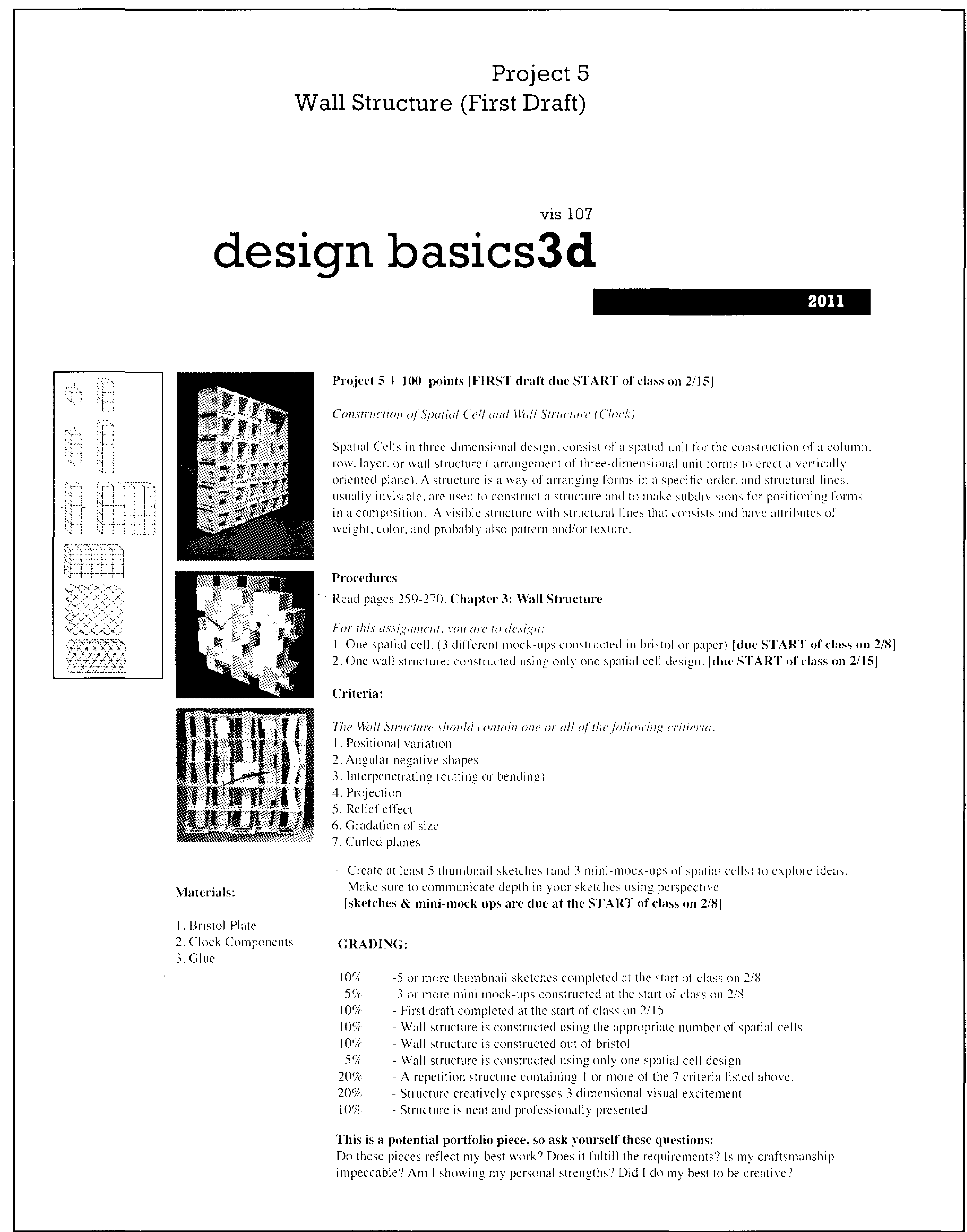

Adapted from Sinclair Community College [VIS 107 Wall Structure Project Assignment Sheet] 
Appendix F

Round Robin All Write Consensus Questions -Second Interruption

\section{CRITIQUE 8}

\section{Get into groups ( 4 or 5 per group). As a group, discuss the following questions ( 2 - 3 minutes per question):}

OBJECTIVE(S)- Rate how effectively each project in your group uses serial planes to communicate volume (1 not effective - 10 very effective)? Discuss with the class how you determined your ratings. What things did people in your group do to create 3 dimensional visual excitement? Choose 1 project the group agrees is the most visually exciting 3 dimensionally and explain to the class why it is.

PROCESS- What was each person's personal process for creating their lamp? What improvements did each person make from the first draft? Why did each person make the changes they chose to make? What would each person do differently (or the same) next time they are asked to design a volume using serial planes?

CRAFTSMANSHIP. Who had the best crafted project in your group? What made theirs the best? What about their personal process contributed to theirs turning out so good? Give the class some craft advice for building a structure with serial planes.

REFLECTION- What was harder (or easier) about designing and constructing the final draft compared to the first draft? Was each person satisfied with how their final draft turned out (why or why not)? Which skills does each group member feel improved for them through working on this project? 


\title{
Appendix G
}

\section{Project 8 Lesson Objectives -Second Interruption}

\author{
Project 8
}

Serial Planes Form(Final Draft)

\section{design basics3d}
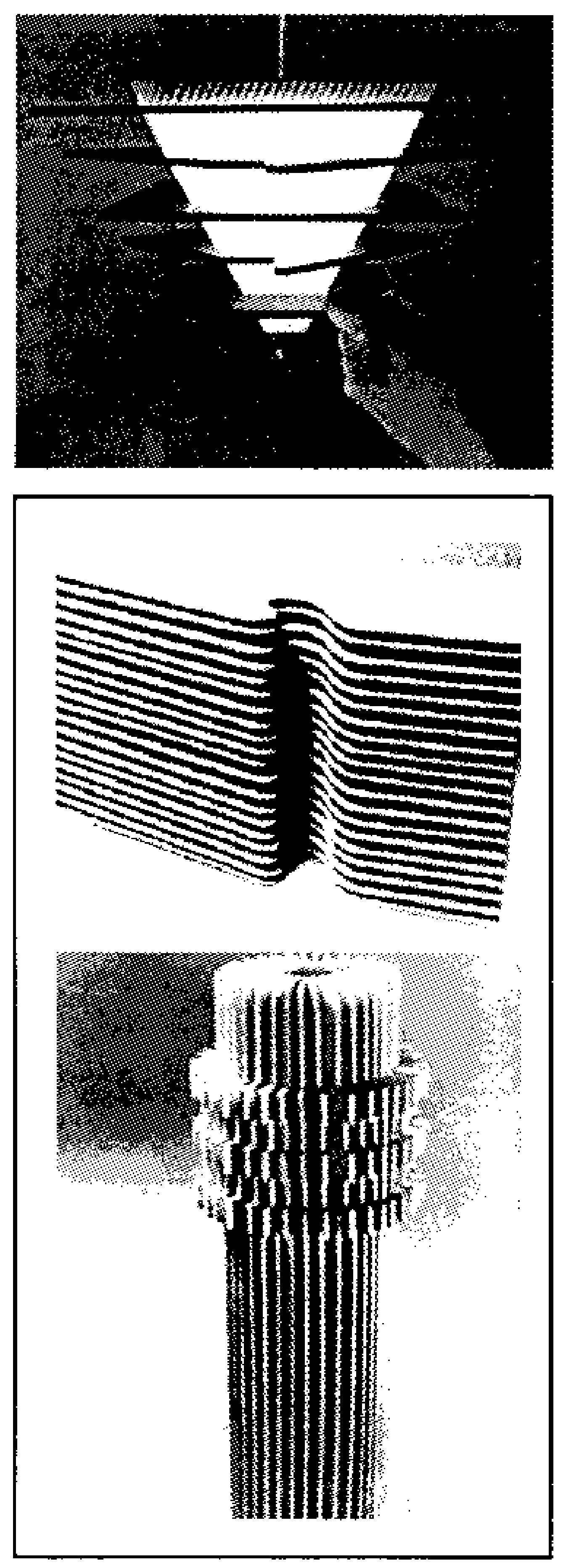

Materials:

1. Foramerone and Plasticore folear) 2. Flectrical light componoms
Project $8 \mid 100$ points [Final draft due START of class on 3/15]

Constration of Sorial Plane Form (wall seonce') fonctional highing somre

Serial Planes are a series of planes orderly arranged in a row 10 sugesest a volumetric form. and form is any visual entity comprising all the visual elements of shape, size, color. and texture. suggesting or embodying plane and/or volume. Shaje is the characteristics of a line or a plane, or the appearance of a form from a particular angle or distance. Shape is the most important element among the visual elements. Shape and form are sometimes used amost synonymously; but shape excludes all references to siz, color, and texture. while form encompasses all such elements.

\section{Procedures}

Read pages 247-258. Chapter 2: Serial Planes

For this assignment, you are to design:

1. One volumetric serial plane lighting source

2. The volumetric structure must be created with i timensional visual excitement.

3. Size should be between 10 and 11 inches squared.

\section{Criteria:}

The volumetric serial plane should contain one or more of the following posinomal varations.

1. Repetition of planes

2. Increased decrease of height

3. Subtle gradation of shape

4. Increasingly sharper angles

5. Gradation of both shape and size

6. The use of concilsily and convexity

7. The use of neative shape

8. I.jght sources

9. Electrical hardwate application

The project will require the use of the Design Process.

After completing research, thumbnails. mini-mock ups and a first draft a plan needs to be made based on feedback you received during the critique. What issues need to be resolved when you make your final draft? Hrite up a plan (consisting of at least

3 sentences detailing what you will focus on improving in your final draft) [revision plan due at ST $A R T$ of class on $3 / 8$ ]

GRADING:

5\% - Plan for revisions (comsisting of at least 3 sentences) due al STAR'] of clatsis on $3 / 8$

$10 \% \quad-$ Final draft completed all the stant of class on $3 / 1.5$

$10 \%-$ Structure is constructed with foamcore at 10 inches $x 11$ inches squared

$5 \%$ - Structure includes a working light component that is well integrated in the design

$25 \%-$ A harmonious volumetric form is evident as serial planes are used to create the structure.

$25 \%$ - Structure creatively expresses 3 dimensional visual excitement

$20 \% \quad-$ Structure is neat and professionally presented (excellent craftsimanship)

This is a potential portfolio piece, so ask yourself these questions:

Do these pieces reflect my best work? Does it fultilt the reguirements? Is my craftsmanship) impeccable? Am I showing my personal strengths". Did I do my best to be creative? 


\section{Appendix $\mathbf{H}$}

\section{Design Faculty Interview Questions}

\section{SINCLAIR INTERVIEW QUESTIONS}

1. How long have you been teaching design?

2. Describe the critiquing process in your design classrooms.

3. What do you do in your critiques to encourage student participation?

4. What do you do in your critiques to address the concerns students have about having their feelings hurt during critiques?

5. Do you ever break the class into groups during critiques? Why or why not?

6. If you do, explain how you break them up. (any goals with the groupings)

7. Are you familiar with the concept of cooperative learning (learning in groups) and cooperative learning structures?

8. If yes, describe what you know about it and how it works.

9. Do you ever use cooperative learning structures and techniques during critiques? Why or why not?

10. What would be some of your concerns (apprehensions) with trying to incorporate cooperative learning structures \& techniques during your design critiques?

11. If you have been using cooperative learning during critiques, what issues do you think might improve its effectiveness?

12. If you have been using cooperative learning during critiques, how do you feel its use affects student participation? Why'? 


\section{Vita}

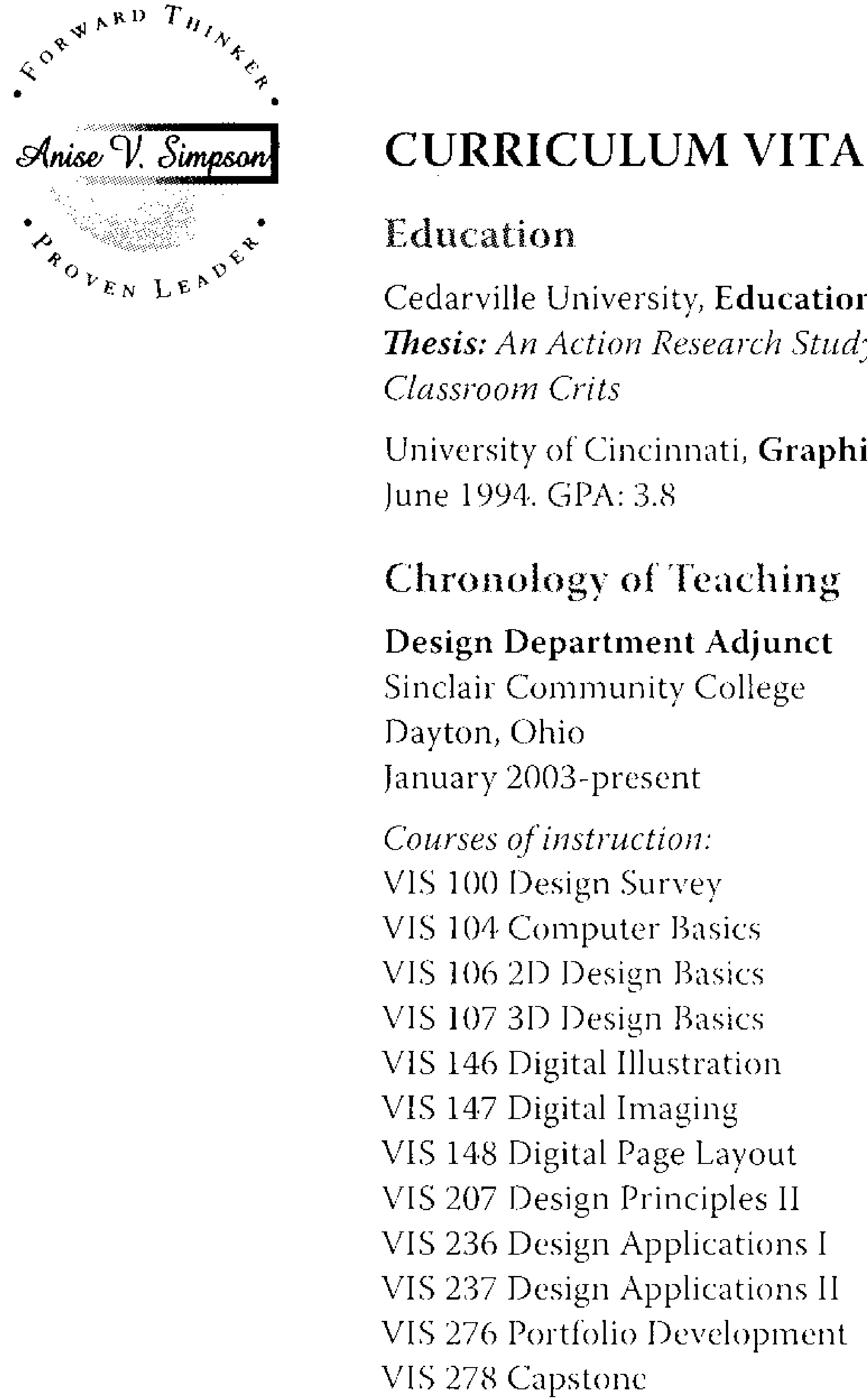

Graphic Design Department Adjunct

Ohio Institute of Photography and Technology Dayton, Ohio

July 2008 -June 2009

Courses of instruction:

GRA-202 Computer Graphics II

GRA-203 Production I

GRA-311 Advanced Design Techniques

Full-Time Graphic Design Instructor

School of Advertising Art

Kettering, ()hio

August 2005-July 2008

Courses of instruction:

CG-104 Intro to Mac OS

CG-118 Intro to Desktop Publishing

GD-119 Point of Purchase

CG-120 Newsletter Cover

CG-140 Intro to QuarkXPress

CG-14.12-Color Brochure

CG-157 Menu Design

CG-159 Poster Campaign

GD-174 Terminology / Proofreading

CG-189 Magazine Cover Design

GE-203 Public Speaking

\section{Publications}

- Arise Academy Charter School Logo Design, American Graphic Design \& Advertising [25], 2010.

- Miami Valley Black Pages Complete Corporate Identity Program Design, American Corporate Identity, 2003.

- Nkey Letterhead Design, American Corporate Identity, 2002.

- Urban Society letterhead Design, American Corporate Identity, 2002.

- The Truth, The Love and The Light! (2008), West Conshohocken: Infinity Publishing.Com [ISBN: 0-7414-4724-X]

80 page guidebook written on the topic of God and Spiritual Growth. Includes journalstyle exercises designed to aid with individual or group Bible study.

Review- by Kahlid Moss, Dayton Daily News, May 2008.

Awards

Professional Design Awards:

- Award of Distinction - Arise Academy Charter School logo Design, American Graphic Design \& Advertising [25], 2010.

- Creative Excellence Award [Best Collateral Piece Honorable Mention 2nd Quarter] - NIE Promo Brochure, Cox Ohio Publishing, 2005.

- Award of Excellence - Miami Valley Black Pages Complete Corporate Identity Program Design, American Corporate Identity, 2003.

- Award of Excellence - Nkey Letterhead Design, American Corporate Identity, 2002.

- Award of Excellence - Urban Society Letterhead Design, American Corporate Identity, 2002.

My Students' Design Awards: (for work students designed during my classroom instruction):

- Gold Award - PF Chang's Menu-student: Reka Juhasz, Greater Dayton Advertising 


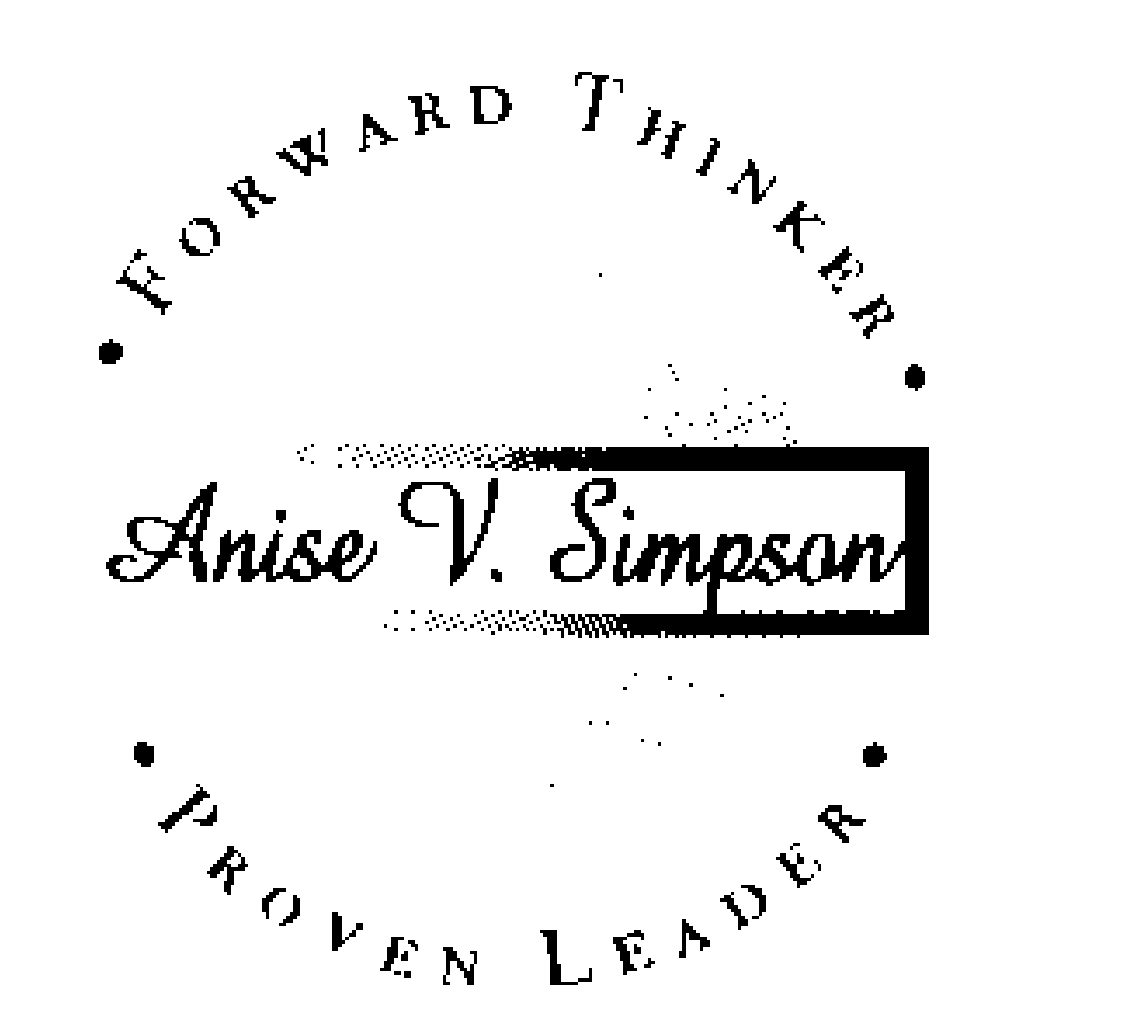

Association 2010 Hermes Awards.

- Silver Award - Olay Ads-student: Chance Graham, Greater Dayton Advertising Association 2007 Hermes Awards.

\section{Professional Experience}

Graphic Designer • Cox Ohio Publishing • Dayton, Ohio • July 2003-August 2005

Designed various marketing materials including; newspaper ads, logos, posters, direct mail pieces and more. These materials were published in the print and online products for the following newspapers: Dayton Daily News, JournalNews, The Middletown Journal, Springfield News-Sun, The Fairfield Echo, Pulse-Journal, Western Star, and Oxford Press.

Senior Production Designer • Huffy Bicycles • Springboro, Ohio • January 1993-November 1999 Designed the production of bicycle graphics including; labels, pads, and point of purchase pieces. Worked closely with Product Managers, Graphic Designers, Local and International Suppliers and Printers.

\section{Entrepreneurial Freelance Experience}

Expertise performing freelance idea creation, graphic design, and production design tasks for the following clients:

ImageWerx 2010, 2009, 2008 • Arise Academy 2008 • Penny-Ohlmann-Neiman 2003 • Willis Case Harwood 2003 • Cox Ohio Publishing 2003 • Cho Graphics 2003, 2000 • ImagineNation 2002

Grass Roots Advertising 2002, 2001 • Ross Communications 2001 • Designed Solutions Group 2001

Visual Marketing Associates 2001, 2000, 1999 • Nkey Music Studios 2000 • Huffy Bicycles 1994, 2000

\section{Computer Skills}

Adobe Creative Suite [Illustrator, InDesign, ['hotoshop, Acrobat Professional] • ANGEI • Black Board I.earning System • Kaplan Quad Campus Portal • QuarkXpress • FreeHand • AdSpeed • Keynote • Microsoft Word • PowerPoint • Outlook • Audacity

\section{Professional Affliations}

- AIGA, the professional association for design [Cincinnati Chapter] (2011): Professional Member.

- Art Center Dayton -Dayton, OH (1999): Local Art Club Member.

- Muse Machine [Chaminade Julienne High School] - Dayton, OH (1989): Visual Arts Team Captain.

\section{Service Affiliations}

- Christian Life Center -Vandalia, ()H (2010-present): Next-Step Small Group Attendee

- Christian Life Center -Vandalia, ()H (2009): Next-Step Small Group Instructional Co-l eader, Swaziland Communications Team Member 